Alaska Department of Natural Resources

Division of Geological \& Geophysical Surveys

\title{
Preliminary volcano-hazard assessment for Fisher volcano, Unimak Island, Alaska
}

Report of Investigations 2014-5
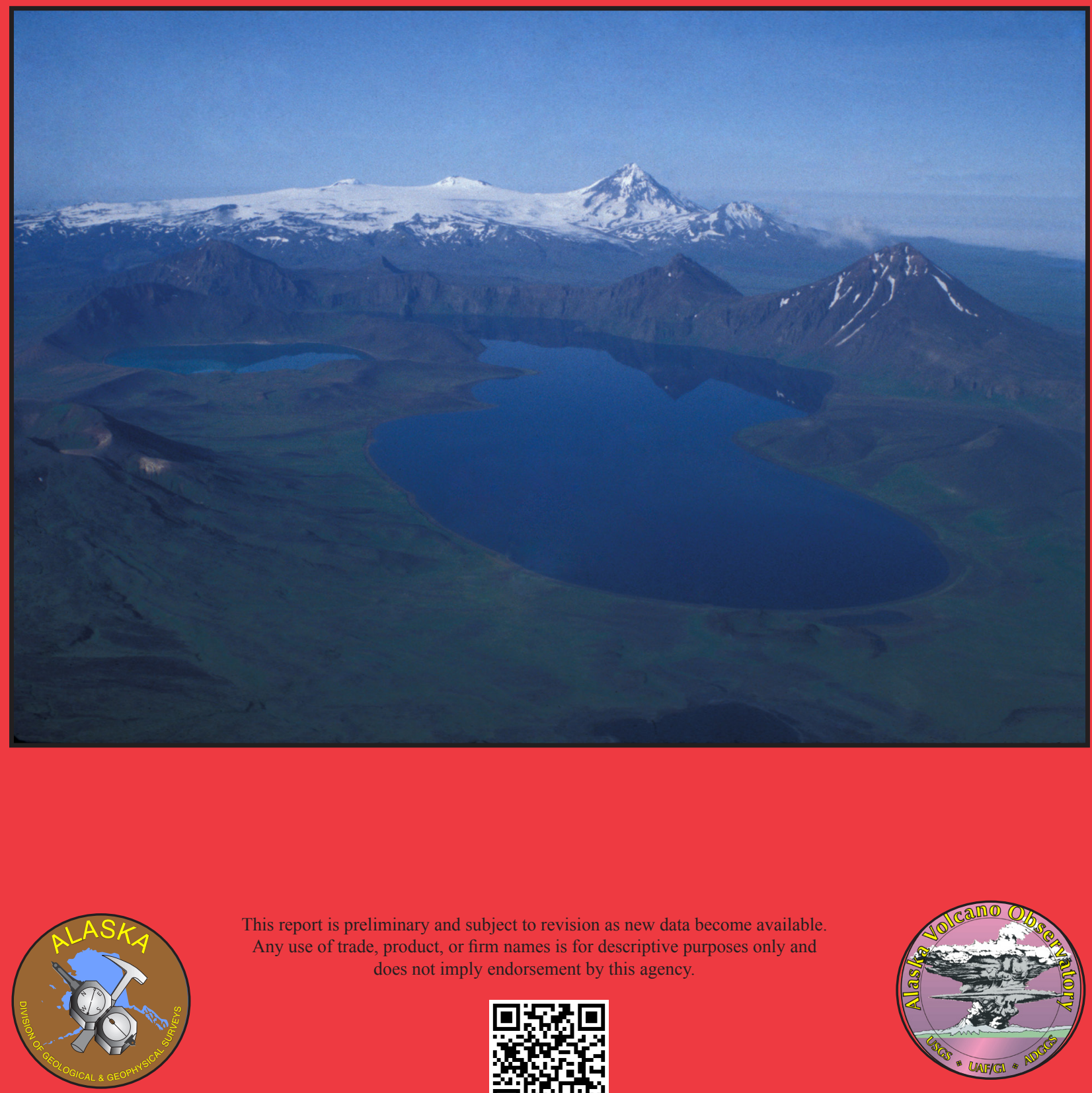

This report is preliminary and subject to revision as new data become available. Any use of trade, product, or firm names is for descriptive purposes only and does not imply endorsement by this agency.
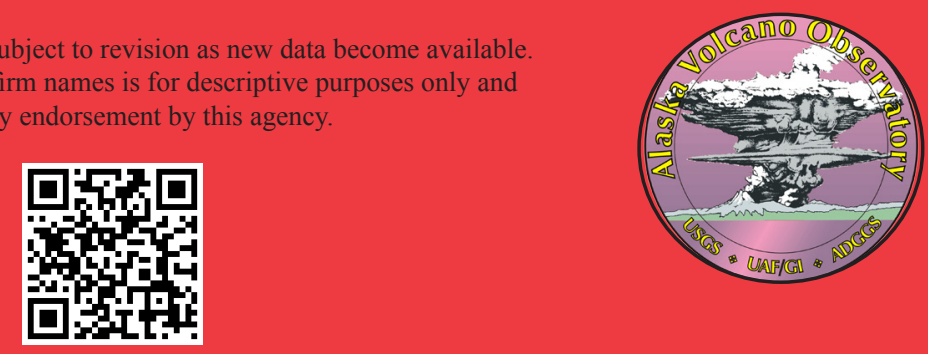
The Alaska Volcano Observatory (AVO) was established in 1988 to monitor dangerous volcanoes, issue eruption alerts, assess volcanic hazards, and conduct volcano research in Alaska. The cooperating agencies of AVO are the U.S. Geological Survey (USGS), the University of Alaska Fairbanks Geophysical Institute (UAF/GI), and the State of Alaska Division of Geological \& Geophysical Surveys (DGGS).

Cover photograph: An aerial view, looking westward, over the western half of the $18 \times 12$ kilometer caldera of Fisher volcano, with the snow-covered Westdahl group of volcanoes (Westdahl, Faris Peak, Pogromni, and Pogromni's Sister, left to right) in the background. The large lake in the foreground is the western caldera lake, the farthest shores of which meet the western caldera wall. On the lower left is Mt. Finch, a small volcanic cone in the center of the caldera. Just above Mt. Finch is Turquoise Lake, the waterfilled depression formed when Turquoise cone collapsed, well after the collapse of the main caldera. The southern caldera rim is just off the photograph to the left, and the northern caldera rim continues off the image to the right. The strip of land along the bottom of the photograph is the isthmus between the eastern and western caldera lakes. The caldera-forming eruption occurred approximately 9,400 years ago, and was the largest volcanic event in Fisher's history. Photograph by Pete Stelling, 1999. 


\author{
Alaska Department of Natural Resources \\ Division of Geological \& Geophysical Surveys
}

\title{
Preliminary volcano-hazard assessment for Fisher volcano, Unimak Island, Alaska
}

by Pete Stelling ${ }^{1}$, James E. Begét ${ }^{2}$, James E. Gardner ${ }^{3}$, and Janet R. Schaefer ${ }^{4}$

Report of Investigations 2014-5

2014

This DGGS Report of Investigations is a final report of scientific research. It has received technical review and may be cited as an agency publication.

${ }^{1}$ Western Washington University, Department of Geology, 516 High St, MS 9080, Bellingham, WA 98225-9080

${ }^{2}$ Alaska Volcano Observatory, Department of Geology and Geophysics, University of Alaska, Fairbanks, Alaska 99775-5780

${ }^{3}$ The University of Texas at Austin, Department of Geological Sciences, 1 University Station C1100, Austin, TX 78712

${ }^{4}$ Alaska Volcano Observatory, Alaska Division of Geological \& Geophysical Surveys, 3354 College Rd, Fairbanks, AK 99709 


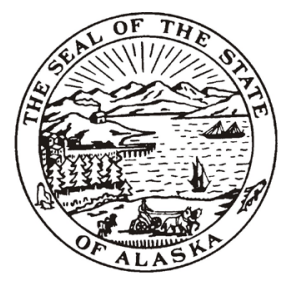

STATE OF ALASKA

Bill Walker, Governor

DEPARTMENT OF NATURAL RESOURCES

Marthy Rutherford, Acting Commissioner

\section{DIVISION OF GEOLOGICAL \& GEOPHYSICAL SURVEYS Steve Masterman, Director and State Geologist}

Division of Geological \& Geophysical Surveys publications can be inspected at the following locations. Address mail orders to the Fairbanks office.

\author{
Alaska Division of Geological \\ \& Geophysical Surveys \\ 3354 College Rd. \\ Fairbanks, Alaska 99709-3707 \\ Elmer E. Rasmuson Library \\ University of Alaska Fairbanks \\ Fairbanks, Alaska 99775-1005
}

\author{
Alaska Resource Library \\ and Information Services (ARLIS) \\ 3211 Providence Drive \\ Anchorage, Alaska 99508 \\ University of Alaska Anchorage Library \\ 3211 Providence Dr. \\ Anchorage, Alaska 99508
}

Alaska State Library
State Office Building, 8th Floor
333 Willoughby Avenue
Juneau, Alaska 99811-0571

This publication, released by the Division of Geological \& Geophysical Surveys, was produced in Fairbanks, Alaska. This Division is authorized by Alaska Statute 41 to publish data it collects and analyzes to fulfill its mission "to determine the potential of Alaskan land for production of metals, minerals, fuels, and geothermal resources; the location and supplies of groundwater and construction materials; the potential geologic hazards to buildings, roads, bridges, and other installations and structures; and shall conduct such other surveys and investigations as will advance knowledge of the geology of Alaska." 


\section{CONTENTS}

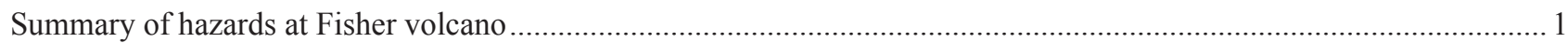

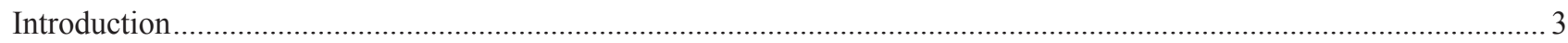

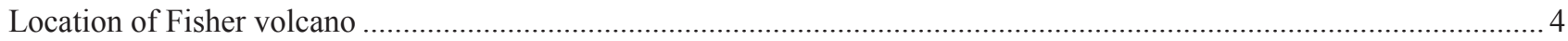

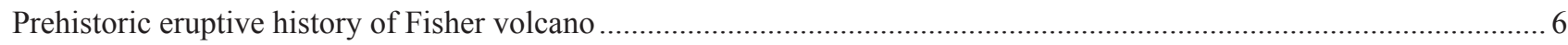

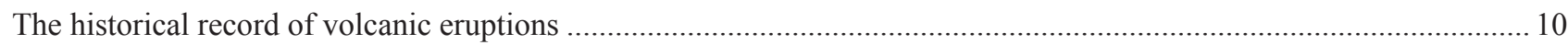

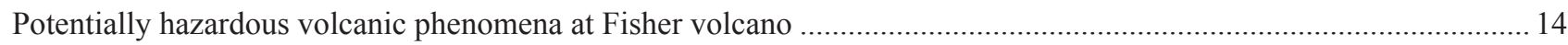

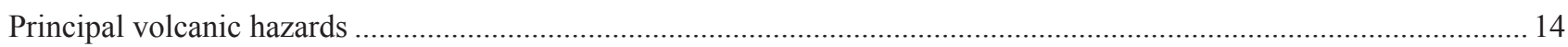

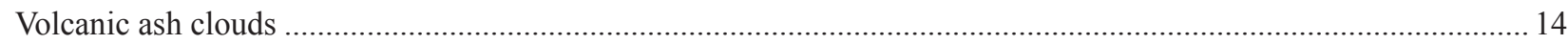

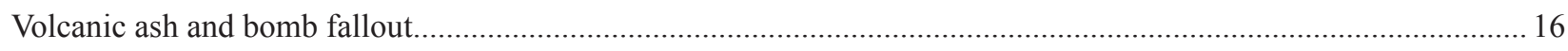

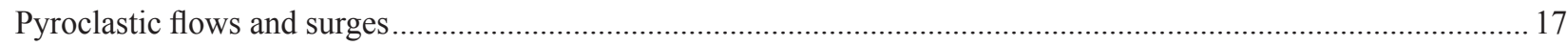

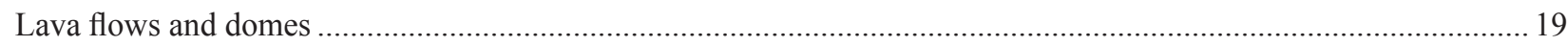

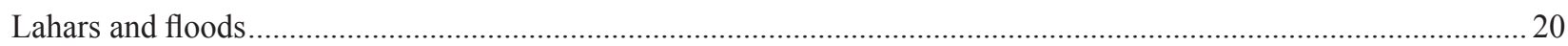

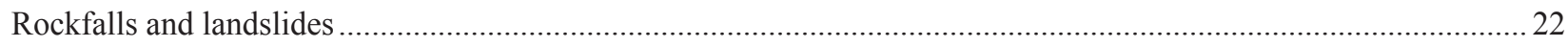

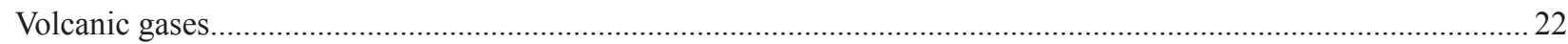

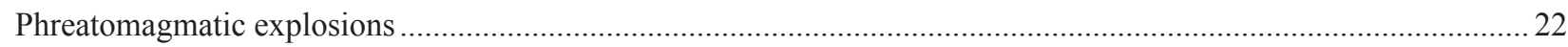

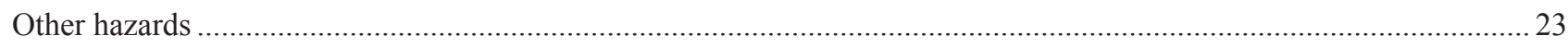

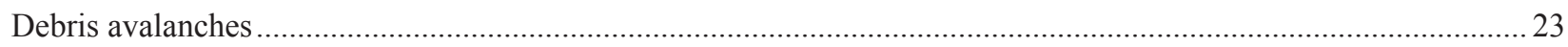

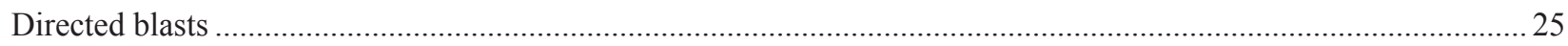

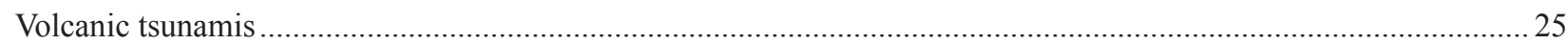

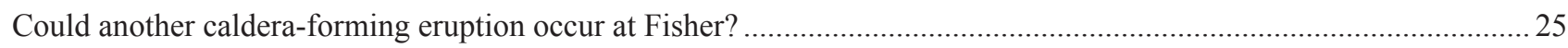

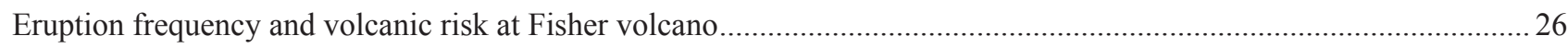

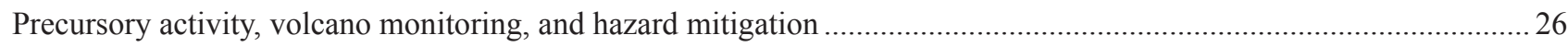

What can be done to prepare for an eruption at Fisher volcano?

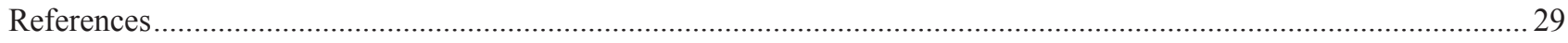

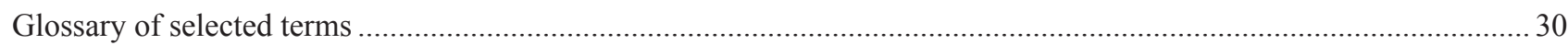

\section{FIGURES}

Figure 1. Location map of Fisher volcano with respect to other historically active volcanoes of Alaska ....................... 4

2. Locations of Fisher volcano and other volcanoes on Unimak Island, and major population centers in the

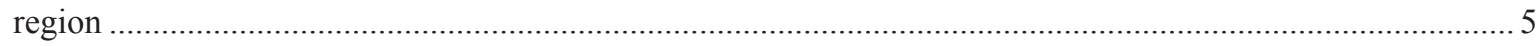

3. Oblique photo, looking toward the southeast, of Fisher volcano ……………............................................... 5

4. View to the northwest of Fisher volcano and prominent geographic features................................................. 6

5. Map of eruptive centers and prominent geographic features of Fisher volcano............................................... 7

6. Deposits from the caldera-forming eruption (CFE) of Fisher volcano

A. Map showing the distribution of the three main deposits from the eruption............................................. 8

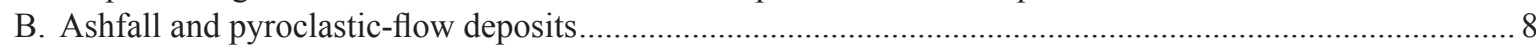

C. Pyroclastic-flow deposits along a creek on the northern flanks of the Tugamak Range near the Bering

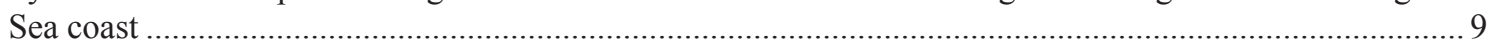

D. Pyroclastic-flow deposits exposed in the west wall of the southern outflow canyon.................................. 9

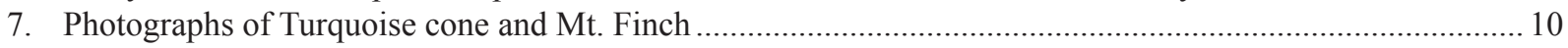

8. Photograph of the southwestern corner of Fisher Caldera as seen from the summit of Mt. Finch................... 12

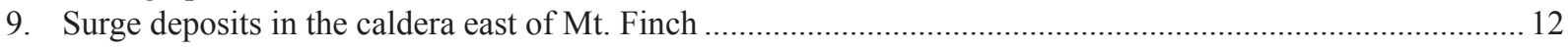

10. Eruption history of Fisher volcano, based on geologic mapping............................................................... 13

11. Simplified sketch of a stratovolcano and associated hazardous phenomena resulting from typical

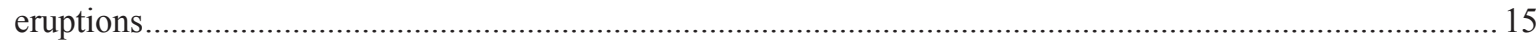

12. Flight paths of commercial freight and passenger aircraft crossing the North Pacific .................................. 16

13. Annual average wind direction over southwestern Alaska ....................................................................... 17

14. Areas that could be impacted by ashfall during an eruption of Fisher volcano.................................................. 18 
15. Areas that could be affected by pyroclastic flows and surges during typical small to moderate future eruptions of Fisher volcano

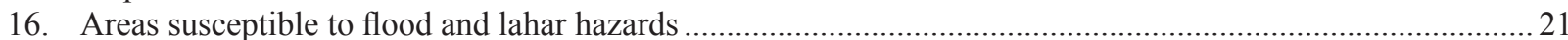

17. Areas of Fisher volcano affected by volcanic gases and thermal upwelling .............................................2 23

18. Maximum likely distribution of material ejected during phreatomagmatic explosions at Fisher volcano.......24

19. Maar craters on the southern shore of the east caldera lake, between Mt. Finch and the eastern caldera rim

20. Locations of seismic monitoring stations on Unimak Island.................................................................2

21. The USGS Alert Notification System for Volcanic Activity and Volcano Alert Levels and Aviation Color Code used by the Alaska Volcano Observatory (AVO)

\section{SHEET}

Sheet 1. Map summarizing volcano hazards at Fisher volcano [in envelope]

\section{Conversion Factors}

\begin{tabular}{|l|l|l|}
\hline \multicolumn{1}{|c|}{ Multiply } & \multicolumn{1}{c|}{ By } & \multicolumn{1}{c|}{ To obtain } \\
\hline millimeter $(\mathrm{mm})$ & 0.03937 & inch \\
\hline centimeter $(\mathrm{cm})$ & 0.39370 & inch \\
\hline meter $(\mathrm{m})$ & 3.2808 & foot \\
\hline kilometer $(\mathrm{km})$ & 0.62137 & mile \\
\hline square kilometer $\left(\mathrm{km}^{2}\right)$ & 0.3861 & square mile \\
\hline cubic meter $\left(\mathrm{m}^{3}\right)$ & 35.315 & cubic foot \\
\hline cubic kilometer $\left(\mathrm{km}^{3}\right)$ & 0.2399 & cubic mile \\
\hline meter per second $(\mathrm{m} / \mathrm{s})$ & 3.2808 & foot per second \\
\hline meter per second $(\mathrm{m} / \mathrm{s})$ & 2.2369 & mile per hour \\
\hline kilometers per hour $(\mathrm{km} / \mathrm{h})$ & 0.62137 & miles per hour \\
\hline
\end{tabular}

Temperature: In this report, temperature is reported in degrees Celsius $\left({ }^{\circ} \mathrm{C}\right)$, which can be converted to degrees Fahrenheit $\left({ }^{\circ} \mathrm{F}\right)$ by the following equation: ${ }^{\circ} \mathrm{F}=\left[\left(1.8 \times{ }^{\circ} \mathrm{C}\right)+32\right]$

\section{THE ALASKA VOLCANO HAZARD ASSESSMENT SERIES}

This report is part of a series of volcano hazard assessments being prepared by the Alaska Volcano Observatory. The reports are intended to describe the nature of volcanic hazards at Alaska volcanoes and show the extent of hazardous areas with maps, photographs, and other appropriate illustrations. The reports are preliminary and subject to revision as new data become available. 


\title{
PRELIMINARY VOLCANO-HAZARD ASSESSMENT FOR FISHER VOLCANO, UNIMAK ISLAND, ALASKA
}

\author{
Pete Stelling ${ }^{1}$, James E. Begét ${ }^{2}$, James E. Gardner ${ }^{3}$, and Janet R. Schaefer ${ }^{4}$
}

\section{SUMMARY OF HAZARDS AT FISHER VOLCANO}

Fisher volcano, containing the largest Holocene caldera in the Aleutian volcanic arc, is an active volcano near the center of Unimak Island, about 120 kilometers southwest of Cold Bay and about 175 kilometers northeast of Dutch Harbor. The volcano is composed of numerous small volcanic centers around and within a large, oval caldera 12 by 18 kilometers in diameter and 500 to 1,000 meters deep that formed during a catastrophic eruption about 9,400 years ago. Since then, more than 30 separate vents inside and outside the caldera have erupted; the most recent eruption occurred in 1826 (Grewingk, 1850; Miller and others, 1998). These eruptions have produced lava flows and widespread tephra (volcanic ash) deposits, and have occasionally been accompanied by large floods and lahars. The history of Fisher volcano includes repeated explosive and non-explosive eruptions of varying levels of intensity, and indicates that this pattern will continue in the future. Understanding the variety of potential hazards associated with different types of volcanic processes typical of Fisher volcano can help minimize the adverse effect of future eruptions on humans and infrastructure.

\section{Volcanic ash clouds}

The generation of clouds of pulverized rock debris, pumice, volcanic ash, and gas that are blasted high into the atmosphere and then drift away from the volcano with the wind is the most prominent hazard associated with future explosive eruptions of Fisher volcano. Ash-rich clouds formed during large eruptions can reach heights of 20 kilometers or more above the volcano. Prevailing winds near Fisher Caldera are from the west, which would carry ash clouds to the east and northeast of the volcano, although dispersal in other directions is possible. The geologic history of Fisher volcano bears evidence of several large eruptions, although most recent eruptions of Fisher have been smaller. All aircraft should avoid flying near ash clouds, as contact with ash particles of any size can damage aircraft windows and instruments, clog air vents, and disable jet engines.

\section{Volcanic ash fallout}

Volcanic ash has been repeatedly erupted from Fisher volcano during the last several thousand years. Typical explosive eruptions can deposit a meter or more of ash up to several hundred meters from erupting vents in the caldera, and up to several centimeters or more of ash can accumulate in areas a few tens of kilometers outside the caldera. Even small amounts of fine ash fallout can cause respiratory problems in some humans and animals. High winds can re-suspend ash and extend the unpleasant effects of ash fallout long after the eruption. Thick deposits of ash fallout can interfere with power generation and electrical equipment, damage air filters and gasoline engines, interrupt radio and cell phone transmissions, and greatly reduce visibility. Thick accumulations of ash form heavy loads, typically weighing ten times as much as an equivalent thickness of snowfall (Johnston, 1997), especially when mixed with rain or snow, and can collapse roofs. Ashfall deposits from the largest eruption of Fisher volcano are up to 12 centimeters thick near the city of Cold Bay, 120 kilometers to the northeast.

\section{Ballistics}

Pebble- to boulder-sized fragments of rock, ice, or pumice can be blasted into the air during explosive eruptions. These fragments follow arcuate, ballistic trajectories away from the vent. These projectiles, called ballistics, fall at high speed, and can injure or kill people on impact, and crush or damage equipment and buildings. Most ballistics will fall within a few kilometers of the vent, but some explosive eruptions hurl ballistics up to a few tens of kilometers.

\section{SUGGESTIONS FOR READING THIS REPORT}

Readers who want a brief overview of the hazards at Fisher volcano are encouraged to read the summary and consult sheet 1 and the illustrations. Individual sections of this report provide a slightly more comprehensive overview of the various hazards at Fisher volcano. A glossary of geologic terms is included and additional information about Fisher volcano may be obtained by consulting the references cited at the end of this report. 


\section{Pyroclastic flows and surges}

Pyroclastic flows (hot, incandescent flows of ash, gas, and coarse volcanic debris) and surges (hurricane-force blasts of turbulent hot gas and ash) can travel down slopes at speeds as great as 100 meters per second, travel 10 to 30 kilometers from the vent, and overtop some obstacles. Multiple eruptions from Fisher volcano have produced pyroclastic flows and surges during the last 10,000 years, including the caldera-forming eruption that sent a pyroclastic flow over the 500-m-high Tugamak Range 15 kilometers north of the vent. Pyroclastic flows and surges generated during future eruptions of Fisher volcano would pose a significant hazard to any people, property, or equipment in the caldera, and rare, unusually large eruptions could send pyroclastic flows or surges to the coastal areas around, or beyond, the volcano.

\section{Lava flows and domes}

Flows of molten rock (lava) could erupt in the future from inside the caldera or from eruptive centers outside of the caldera. These flows would probably move slowly, at rates of only a few meters to tens of meters per hour, and pose little hazard to humans. These flows could develop steep, blocky fronts, and avalanching of blocks from the flow could be hazardous to anyone close to an active lava flow front. Lava flows from vents in the caldera are unlikely to reach the flanks of the volcano.

\section{Lahars and floods}

During an eruption, the rapid release of water from lakes in the caldera can produce large floods of water and volcanic debris. Hot volcanic debris erupted onto the flanks of the volcano can also melt snow, forming lahars, which are floods or fast-moving slurries of water, mud, rock, and sand. Lahars can also occur when thick deposits of proximal ash are rapidly eroded by heavy rainfall following eruptions. Lahars and floods are most likely to originate on the upper flanks of the volcanic cones, and thus could affect any areas near streams and valleys on the lower flanks. Lahars follow stream paths and are typically restricted to stream valleys and nearby low-lying areas.

\section{Rockfalls and landslides}

The steep crater walls surrounding the caldera, and bedrock cliffs, volcanic cones, and steep lava flows are prone to rockfalls and small landslides. The frequency and size of such events is likely to increase during future eruptions and earthquakes.

\section{Volcanic gases}

Volcanic vents typically emit steam and gases, including hydrogen sulfide and carbon dioxide, in concentrations that are potentially harmful to humans. In 1999 and 2000, fumaroles on the upper flanks of Mt. Finch were intermittently active. Hot gases released into bodies of water in the caldera have formed several hot springs. Lava flows and pyroclastic flows also emit large amounts of steam and gas. Dangerous, invisible, odorless volcanic gases such as carbon dioxide can collect in low-lying areas near fumaroles, creating a potential hazard in craters, caves, or fissures occupied by fumaroles. The amount of gas emitted by Fisher volcano is likely to increase to dangerous levels during future eruptions, making it unsafe to closely approach active fumaroles associated with craters, lava flows, and domes.

\section{Phreatomagmatic explosions}

Contact between magma and water can result in a violent explosion known as a phreatomagmatic eruption. These eruptions generally produce low-altitude eruption plumes and can eject volcanic material ballistically up to 10 kilometers from the vent. Very intense phreatomagmatic activity can generate pyroclastic surges (see above). Steep-walled craters, called maars, are often formed as a result of the high explosivity of eruptions when magma contacts groundwater. The vents of these types of eruptions are difficult to anticipate, as they typically occur in areas that have not had any prior eruptive activity. There are several maars in the caldera, and thick (up to 100 meters) phreatomagmatic deposits are found in many locations inside and outside the caldera. Phreatomagmatic eruptions have affected more than 450 square kilometers at Fisher Caldera.

Some varieties of hazardous phenomena occur rarely, but might possibly accompany extremely large future eruptions of Fisher volcano. These include:

\section{Directed blasts}

A directed blast is a laterally directed explosion of the volcano caused by rapid release of internal pressure. Most directed blasts are caused by a slope failure of newly emplaced lava domes, or sector collapse of the summit edifice into a debris avalanche (see below), resulting in rapid decompression of a shallow magma body. Directed blasts can destroy structures in a large radial zone extending 10 to 25 kilometers away from the source of the blast. The caldera-forming eruption at Fisher volcano $\sim 9,400$ years ago produced a pyroclastic flow that may have resulted from a directed blast. The collapse of Turquoise cone may have also been associated with a direct blast. 


\section{Debris avalanches}

Debris avalanches are rapidly moving masses of rock debris produced by large-scale landslides and rockfalls that travel many kilometers from their source, burying everything in their path. Debris avalanches can be triggered by eruptions, volcanic earthquakes, or regional earthquakes, or they can occur without an obvious cause other than gravitational failure. Slope failure of any of the larger eruptive centers associated with Fisher volcano could produce a debris avalanche capable of traveling tens of kilometers from source. The collapse of Turquoise cone most likely produced a significant debris avalanche inside the caldera. The hazard from debris avalanches is limited to areas around prominent topographic features inside and outside the caldera, including the western and northern stratocone complex, the eastern caldera wall, Turquoise cone, and Mt. Finch inside the caldera and older volcanic structures outside the caldera. Smaller-scale debris avalanches and rockfalls can also occur from the steep margins of thick, active lava flows or large, growing lava domes.

\section{Volcanic tsunamis}

Debris avalanches, pyroclastic flows or lahars, or directed blasts that travel into the sea or lakes can displace water and generate unusually large waves, also known as volcanic tsunamis. Volcanic earthquakes, explosions, or other eruptive processes can also produce tsunamis. If an eruption were to occur beneath the lakes in Fisher Caldera, it is possible that such waves could inundate areas around the lake shorelines and cause flow over the lower caldera walls. Volcanic tsunamis in the ocean are much less likely, but pyroclastic flows produced during the caldera-forming eruption about 9,400 years ago could have traveled many kilometers into the sea beyond the flanks of the volcano and over the Tugamak Range, which likely generated tsunamis. Although an eruption of Fisher volcano of sufficient magnitude to send large volumes of pyroclastic material into the Pacific Ocean or Bering Sea is highly unlikely to recur in the near future, such an eruptive event and the resultant volcanic tsunami would pose a risk to low-lying coastal areas around the shores of Unimak Island, Akun and Akutan Islands to the west, the westernmost Alaska Peninsula including the cities of King Cove and Cold Bay, and the eastern shores of Unalaska Island including Dutch Harbor.

\section{INTRODUCTION}

Fisher volcano, also referred to formally as Fisher Caldera, is part of the Aleutian volcanic arc, which comprises 52 historically active volcanoes extending over 2,000 kilometers from the far western end of the Aleutian Islands to the Cook Inlet area of south-central Alaska (fig. 1; sheet 1). The Aleutian arc is one of the most volcanically active regions on Earth, with eruptions typically occurring every year at one or more of the volcanoes. During the last several hundred years, Fisher volcano has experienced little eruptive activity (Miller and others, 1998; Stelling and others, 2005). Despite unverified reports of eruptions in 1795, 1826, and 1830, ash deposits on the caldera floor suggest a single eruption, from Mt. Finch, has occurred in historic time. It is likely that at least two of these three reports were erroneously attributed to Fisher and were likely flank eruptions of nearby Shishaldin volcano (Stelling and others, 2005).

Fisher Caldera lies in the geographic center of Unimak Island, between Shishaldin Volcano to the east and Westdahl volcano to the west (fig. 2). Fisher is a complex of multiple stratovolcanoes covering approximately 650 square kilometers centered around an oval-shaped caldera, $12 \times 18$ kilometers in diameter, that formed during a single large eruption about 9,400 years ago (Stelling and others, 2005). The caldera has since been partially filled with lava flows, tuff cones, cinder cones, and other volcanic deposits (figs. 3-5). The crater rim reaches to 1,112 meters in elevation, and stands 100 to 900 meters above the caldera floor. The caldera walls expose the interiors of several pre-caldera stratocones, showing numerous lava flows, pyroclastic-flow deposits, debris-flow deposits, and scoria-fall deposits emplaced early in the history of Fisher volcano. Three lakes are present inside the caldera, one informally named Turquoise lake, at the base of Turquoise cone, its color resulting from two larger, unnamed lakes (fig. 4). The creek flowing through the southern caldera canyon originates from seeps through the dam formed by Turquoise cone and Mt. Finch, and is the only surficial drainage flowing out of the caldera.

Before its caldera-forming eruption and subsequent collapse, Fisher volcano consisted of at least eight pre-caldera stratocones, all of which were partially destroyed in the caldera-forming eruption (Stelling and others, 2005). The largest of these cones is named Eickelberg Peak (1,112 meters in elevation), which forms part of the northwest caldera wall (figs. 4 and 5). Between these peaks are gentle slopes that have been largely buried by pyroclastic flow, volcanic ash, and phreatomagmatic and debris-avalanche deposits. Eroded lava flows form several prominent structures around the outside of the caldera, which represent the oldest volcanic features associated with Fisher volcano (about 600,000 years old; Stelling and others, 2005). A single post-caldera stratocone and ridge formed to the northwest outside the caldera, and a cluster of three cinder cones and a coeval lava flow that extends almost 9 kilometers to the southern coast developed after the caldera-forming eruption. Two large stratocones, Turquoise cone and Mt. Finch (figs. 4 and 5), have developed inside the caldera, each producing multiple ash, ballistic, and lava-flow deposits. At least 15 monogenetic eruptive centers are present in the caldera that have formed ash, cinder-cone, lava-flow, and/or phreatomagmatic deposits. Monogenetic vents are more common in the northern part of the caldera. 


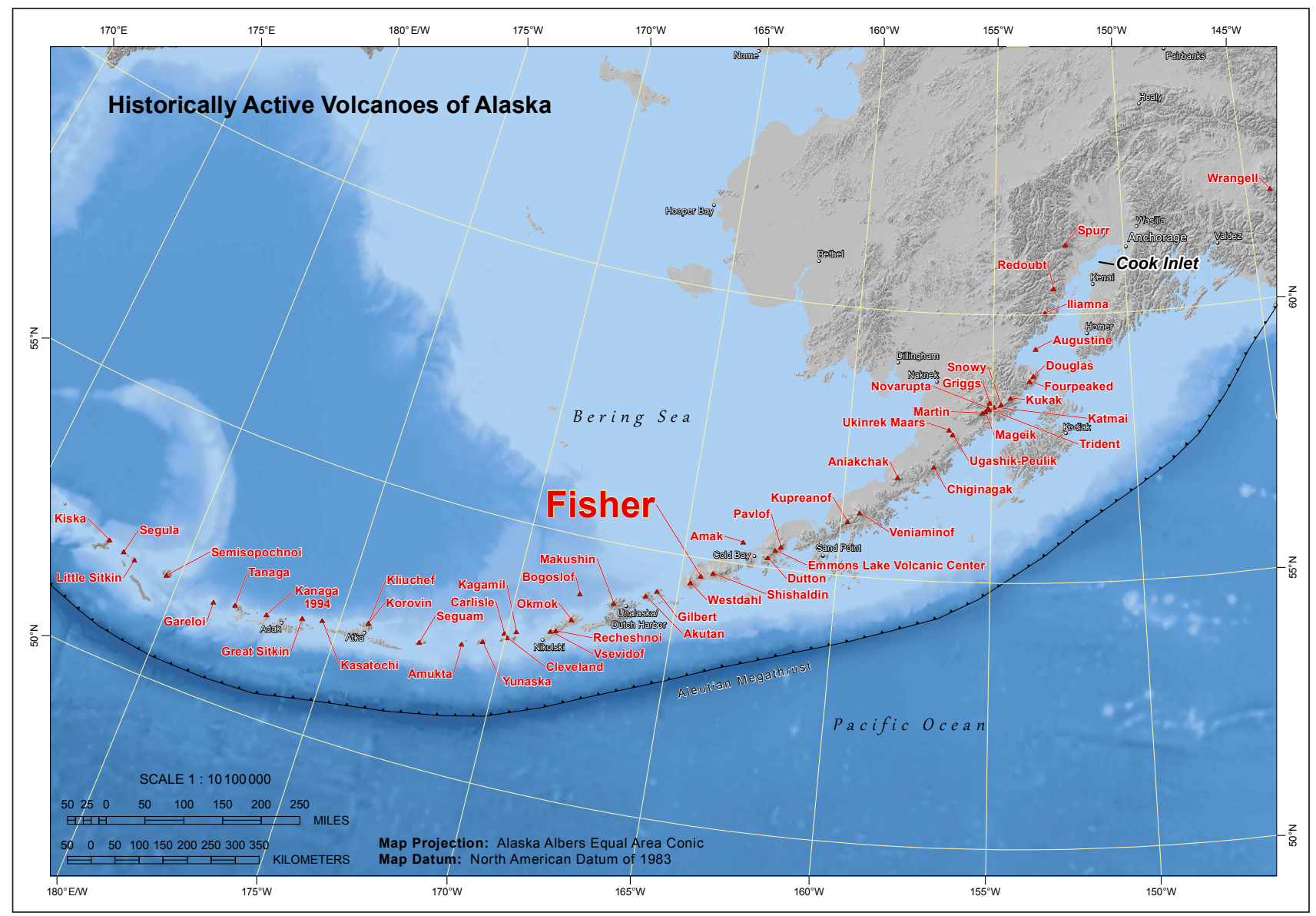

Figure 1. Location of Fisher volcano with respect to other historically active volcanoes of Alaska. All of these volcanoes have erupted in the last 250 years and are considered active and capable of future eruptions. Figure modified from Schaefer and others, 2014.

Assessment of the volcanic hazards at Fisher volcano is made on the basis of the historical record of eruptions during the past 250 years combined with geologic evidence of the behavior of the volcano during the last 600,000 years. The past eruptive history of Fisher volcano is the best indicator of likely events and scenarios that could occur during future eruptions. This report discusses the effects of eruptions on parts of Unimak Island surrounding Fisher Caldera, as well as on areas at greater distances from the volcano, and constitutes the first comprehensive report on possible hazards associated with future eruptions of Fisher volcano. The present status of volcano monitoring efforts and the procedure for eruption notification and dissemination of information are also discussed. This report includes maps and illustrations that indicate potential hazard zones associated with different types of eruptions. A glossary of volcanic and geologic terms is also included.

\section{LOCATION OF FISHER VOLCANO}

Fisher volcano is located near the middle of Unimak Island (fig. 2) in the eastern Aleutian Islands, about
1,150 kilometers southwest of the city of Anchorage and 120 kilometers west of Cold Bay. Fisher volcano is part of the Aleutian volcanic arc that extends more than 2,000 kilometers across southern Alaska and the Aleutian Islands (fig. 1). The Aleutian arc is one of the most volcanically active areas in the world (Miller and others, 1998; Simkin and Siebert, 1994).

The only populated area on Unimak Island is False Pass, a city of 68 people $^{1}$ on the easternmost end of the island. Cold Bay, the largest year-round population center (population 108) on the Alaska Peninsula, and King Cove (seasonal population maximum 938) are 120 kilometers northeast of Fisher Caldera. The city of Akutan (maximum seasonal population 1,027) is 85 kilometers west of Fisher, and Unalaska, the largest city in the Aleutian Islands with a population of 4,376 , is about 175 kilometers to the southwest.

Unimak Island was occupied during World War II by U.S. Army and Air Force troops, who built roads, airstrips, and buildings centered around the Cape Sarichef lighthouse and LOng RAnge Navigation (LORAN) station complex

${ }^{1}$ Population data in this report are taken from the 2010 U.S. Census. 


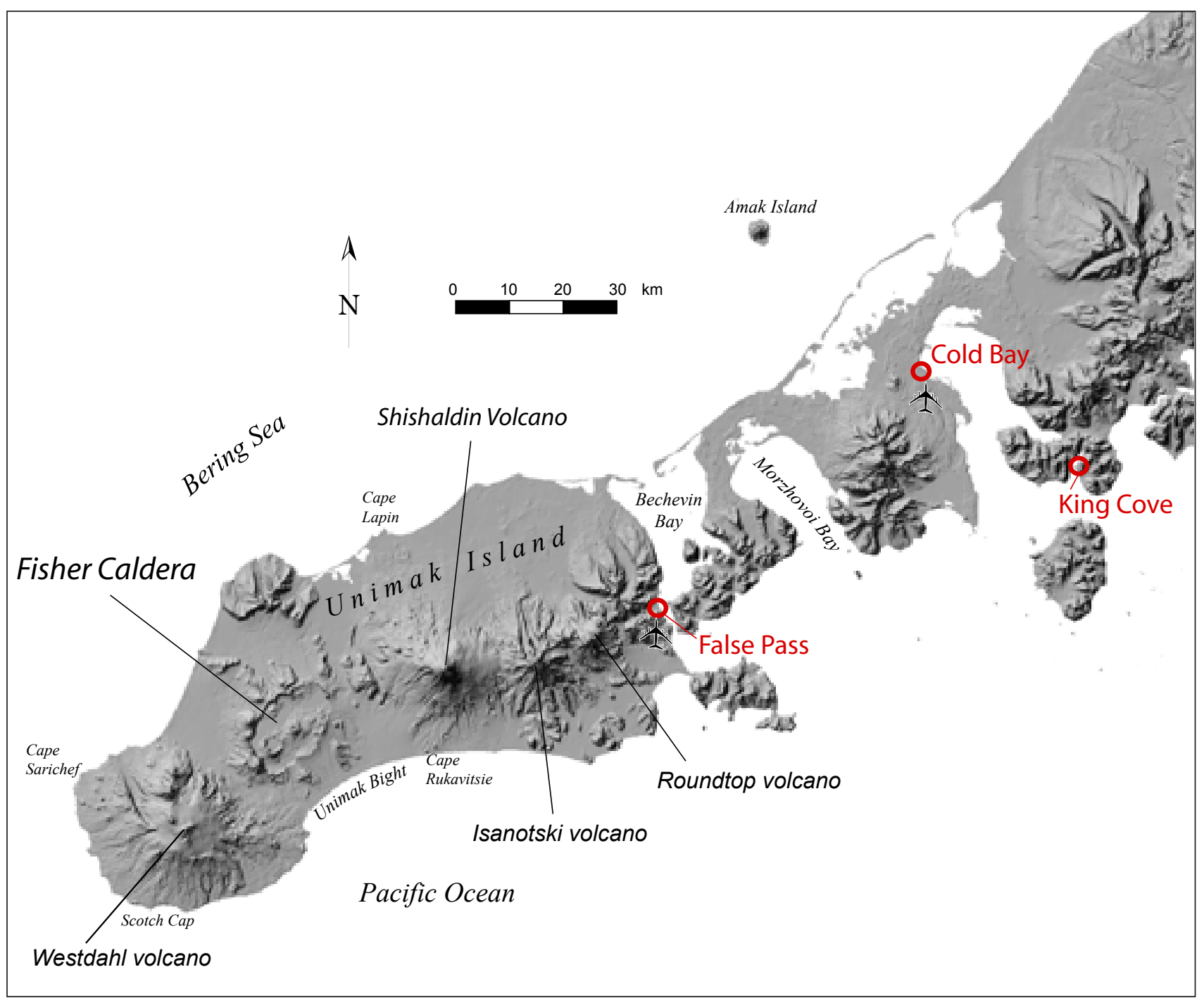

Figure 2. Locations of Fisher volcano and other volcanoes on Unimak Island. Also shown are locations of major population centers in the region: False Pass, Cold Bay, and King Cove.

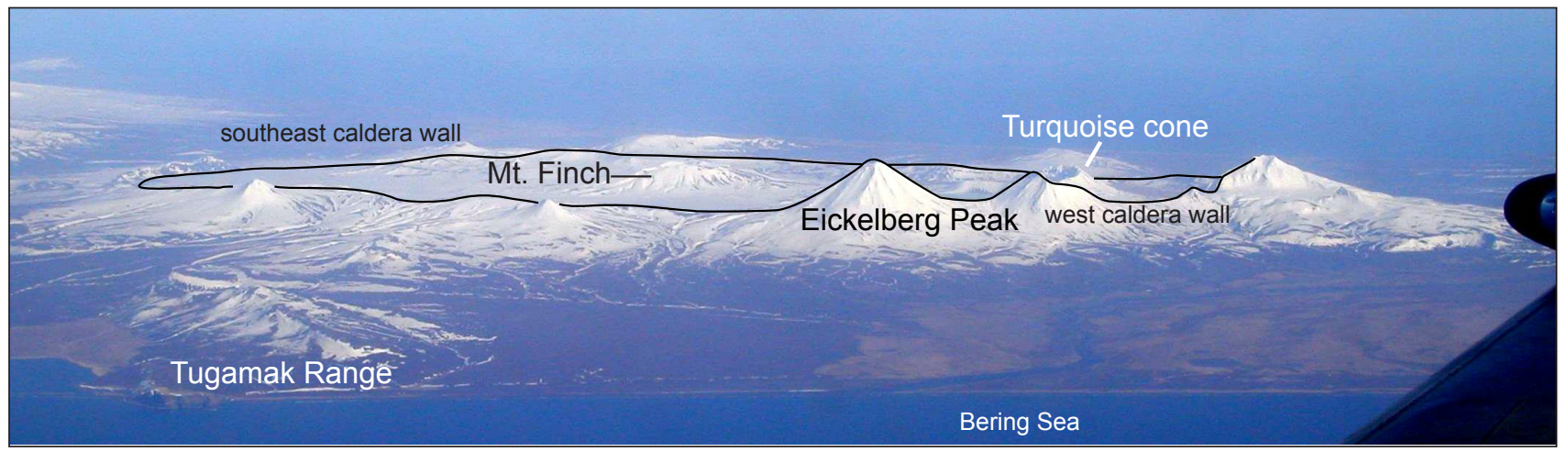

Figure 3. Oblique photo, looking toward the southeast, of Fisher volcano. The caldera rim is indicated with a black line. The peaks on the right are the stratocones of the western caldera wall that were severed during the caldera-forming eruption. In this image the snow line extends about 1 kilometer below the caldera rim. The small, rounded mound in the geographic center of the caldera is Mt. Finch. The snow-capped hills on the lower left are the Tugamak Range. Photo by J. Eichelberger, 2002. 
and the Scotch Cap lighthouse, both on the western end of Unimak Island. The Scotch Cap lighthouse was destroyed by a tsunami in 1946, and the Cape Sarichef lighthouse was decommissioned in 1979. Since 1979, these areas have not been regularly occupied and all valuable property has been removed.

The Bering Sea and the North Pacific Ocean surrounding Fisher Caldera are some of the most productive fisheries in the world, and at almost any time of the year commercial fishing boats pass by and work around Unimak Island. The port of Dutch Harbor and adjacent city of Unalaska, on the eastern end of Unalaska Island, are home to many of the fishing boats and constitute one of the largest commercial fishing ports in North America.

Economic development near Fisher Caldera is presently limited. It is possible, however, that increased tourism, development of geothermal resources, and other activities could occur around Fisher in the future.

\section{PREHISTORIC ERUPTIVE HISTORY OF FISHER VOLCANO}

The prehistoric volcanic deposits of Fisher were first studied by Miller and Smith (1977), and other topical investigations were conducted by Fournelle (1990) and Bindeman and others (2002). Alaska Volcano Observatory personnel conducted geologic studies at Fisher in 1999 and 2000. These studies include field investigations at more than 300 localities, geologic mapping of the entire volcano, stratigraphic correlations for all deposits possible, and petrologic research to better understand the magnitude and history of past volcanism.

The written record of eruptive activity at Fisher volcano begins only 250 years ago, hence geologic and geochronologic studies were made of the deposits of prehistoric eruptions to estimate the long-term style, magnitude, and frequency of volcanism. Fisher has been the site of nearly continuous volcanic activity for at least a half million years, as indicated by radiometric dating of lava flows at the base of remnant flow sequences around the outside of the caldera. The eruptive history of Fisher is highlighted by a single, colossal, caldera-forming eruption that multiple radiocarbon dates indicate occurred about 9,400 years ago. Many deposits of Pleistocene age produced by eruptions of Fisher have either been buried by younger volcanic deposits or removed by glacial erosion. As a result, a detailed record of volcanic activity at Fisher volcano can be reconstructed only since the end of the last ice age (that is, during the last 10,000 years, roughly since the caldera-forming eruption), and less detailed but significant observations can be made about the eruptive history prior to the last major glacial episode ending $\sim 10,000$ years ago.

Prior to the caldera-forming eruption, Fisher volcano was a complex of at least eight small stratocones distributed across a broad $\sim 650$-square-kilometer region. The youngest stratocones prior to the caldera-forming eruption developed on the western edge of the modern caldera, through an apparent northward migration of vents such that deposits of the northern cones lie stratigraphically above their southern

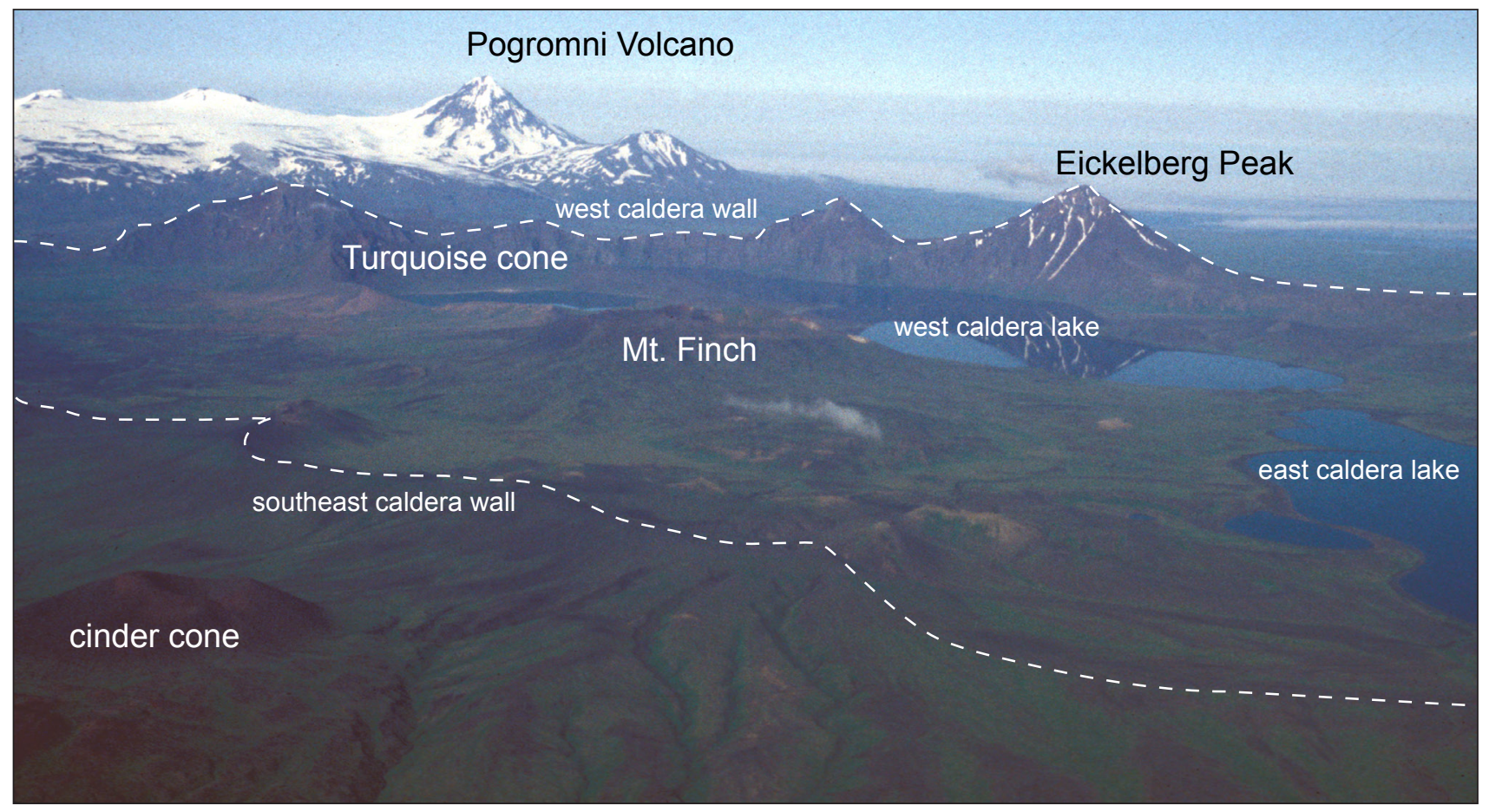

Figure 4. Photo of Fisher volcano and prominent geographic features; view is to the northwest. The width of view is about 14 kilometers, and the caldera extends another 5 kilometers to the right (east). The dashed white line outlines the caldera rim. Photo by P. Stelling, 2000. 
neighbors. The last stratocone to form prior to the caldera-forming eruption was Eickelberg Peak, the largest of the pre-caldera cones (figs. 4 and 5).

The caldera-forming eruption produced three separate deposits that are distributed in nearly all directions (fig. 6A). The eruption began with a large eruption column that produced thick pumice and ash deposits predominantly to the north and east (fig. 6B), as thick as 10 meters in proximal locations. The most distal identified deposit is 120 kilometers to the northeast near Cold Bay where it is up to 12 centimeters thick (Bindeman and others, 2002; Carson and others, 2003; Funk, 1973). Based on the distribution of pumice-fall deposits (fig. 6A), this phase of the eruption was likely vertical with significant wind shear to the northeast. The second phase of the caldera-forming eruption involved the generation of a large pyroclastic flow that traveled primarily to the north (fig. 6C). The flow traveled more than 20 kilometers, surmounting the 500-meter-high Tugamak Range. Deposits on top of the Tugamak mountains are $\sim 30$ centimeters thick but rapidly thicken to the north to 3.5 meters in the head of one valley and greater than 30 meters about 25 kilometers away on the northern coast beyond the Tugamak Range, indicating that a significant volume of the pyroclastic flow was deposited offshore in the Bering Sea (Stelling and others, 2005; Gardner and others, 2007). Deposits 32 kilometers to the northwest on Cape Lapin are more than 1 meter thick. The third phase of the caldera-forming eruption produced a separate, south-directed pyroclastic surge and flow, leaving deposits more than 3 meters thick up to 6 kilometers outside the southwest corner of the modern caldera, and not observed beyond this distance (figs. 6A and D). This pyroclastic surge and flow deposit directly overlies a debris-avalanche deposit (fig. 6D). The gradational nature of the contact between the debris-avalanche and pyroclastic-surge deposits of the caldera-forming eruption suggest this phase of the eruption could have been locally associated with the collapse of a pre-caldera volcanic structure.

Volcanism at Fisher continued episodically after the caldera-forming eruption. Lacustrine deposits at many localities inside the caldera indicate a large lake once filled

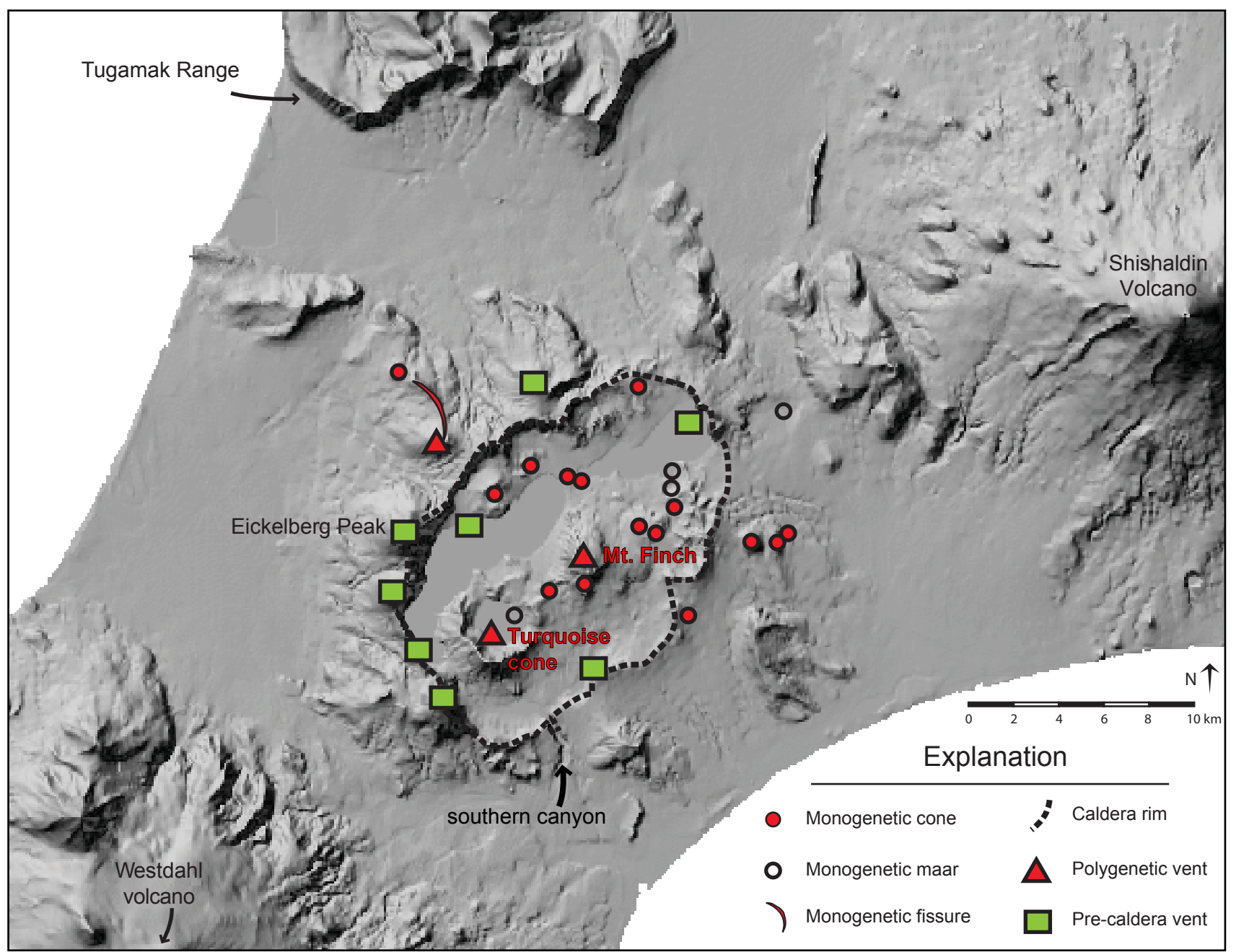

Figure 5. Map of eruptive centers and prominent geographic features of Fisher volcano. See explanation for details. Monogenetic vents have had only one eruptive episode; polygenetic vents have had multiple eruptive episodes. 
Figure 6. Deposits from the caldera-forming eruption (CFE) of Fisher volcano. A. Map showing the distribution of the three main deposits from the eruption. Dashed lines indicate thickness (in meters) of ash deposits; yellow area is the northern pyroclastic flow deposit; and tan areas are the southern pumice flow deposit. Dark gray hexagons are estimated vent locations for the caldera-forming eruption. Light gray dash-double-dot curve is the caldera rim; blue areas are water (streams, lakes); and the gray area represents the central portion of Unimak Island. B. Ashfall and pyroclastic-flow deposits. At this site, $\sim 5$ kilometers from the caldera, the lower deposits are pumice-fall, $\sim 6$ meters thick, overlain by about 2 meters of densely welded pyroclastic flow material. Additional pyroclastic flow material above is obscured by slope wash. Photo: P. Stelling, 2000.
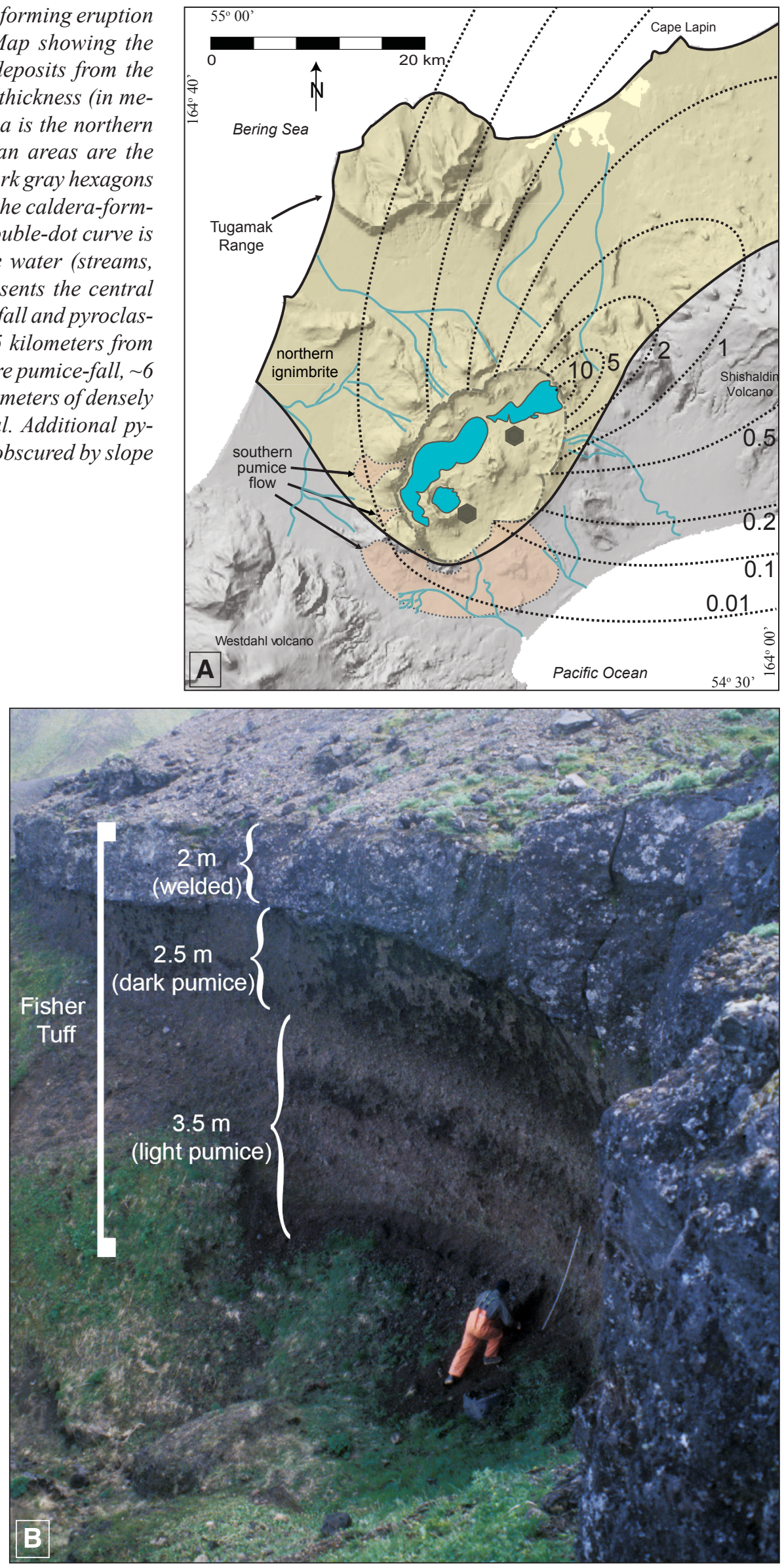

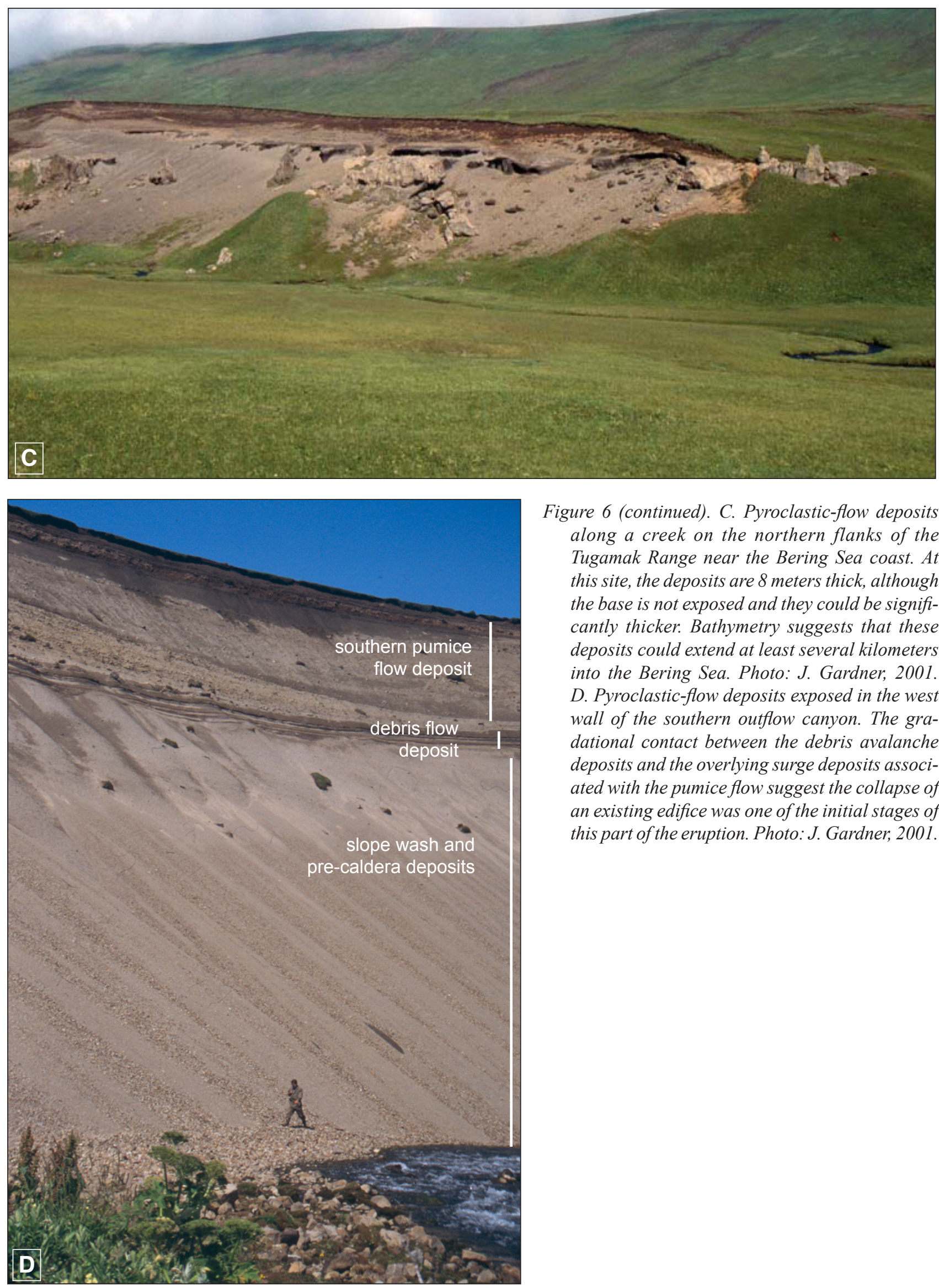

Figure 6 (continued). C. Pyroclastic-flow deposits along a creek on the northern flanks of the Tugamak Range near the Bering Sea coast. At this site, the deposits are 8 meters thick, although the base is not exposed and they could be significantly thicker. Bathymetry suggests that these deposits could extend at least several kilometers into the Bering Sea. Photo: J. Gardner, 2001. D. Pyroclastic-flow deposits exposed in the west wall of the southern outflow canyon. The gradational contact between the debris avalanche deposits and the overlying surge deposits associated with the pumice flow suggest the collapse of an existing edifice was one of the initial stages of this part of the eruption. Photo: J. Gardner, 2001. 
most of the caldera; lake sediments are interstratified with at least 25 ash and scoria layers associated with minor explosive eruptions from Fisher or from nearby Westdahl and Shishaldin volcanoes.

Two large stratocones have developed in the caldera: Turquoise cone and Mt. Finch (figs. 4, 5 and 7). These cones were formed through repeated eruptions of lava and ash, and could have been the source of the scoria and ash layers incorporated in the lake sediments. Both cones have collapsed, though the collapse of Turquoise cone (estimated to be approximately 3 cubic kilometers based on extrapolation of strata exposed in the cone walls) was significantly larger than that of Mt. Finch (less than 0.1 cubic kilometers estimated volume missing from the summit; fig. 7B). The modern Turquoise cone represents about one-third of the original stratocone, assuming an originally conical shape. The collapse of Turquoise cone followed two explosive eruptions that each produced nearly 1-meter-thick deposits of coarse pumice 15 kilometers away. At least one of these eruptions deposited a 3-centimeter-thick layer of pumice 120 kilometers to the northeast near Cold Bay (Carson, 1998). In addition to the explosive portion of these eruptions, a lava flow was produced, which buried the entire western half of Turquoise cone under at least 5 meters of lava. Radiometric dates of lake deposits on shores of Turquoise lake indicate that the collapse must have occurred more than about 3,500 years ago (Stelling and others, 2005).

The caldera was, at one point, completely filled with water to a maximum depth of $\sim 100$ meters, as evidenced by beach deposits high on the inside of the caldera rim (fig. 8). An explosive phreatomagmatic eruption occurred from within the collapsed Turquoise cone area about 1,500 years ago and likely generated a tsunami in the caldera lake that spread radially (Stelling and others, 2005). Tsunami wave deposits from the collapse of Turquoise cone and subsequent phreatomagmatic eruptions are present at the north shore of the modern western caldera lake and on the isthmus between the northern lakes, along with erosional scars from the waves. The most dramatic effect waves had on the caldera was on the southern wall, where a wave overtopped the caldera rim. Cobbles from a wave-cut terrace on the southern wall have been lifted $\sim 20$ meters higher onto the top of the caldera wall. The resistant, caldera-forming eruption deposit that caps the southern caldera wall was incised, and the wave at least partly eroded the softer underlying deposits in the wall to form a canyon below lake level. The combined erosion of the tsunami and the newly-draining lake carved the modern 100-meter-deep southern outflow canyon (figs. 6D and 8), allowing the lake to drain catastrophically. Had the lake drained gradually through incremental erosion of the southern outflow canyon, beach deposits reflecting periods of lower lake levels would be present along the inner caldera wall. The absence of these deposits, as well as the presence of large boulders (up to 5 meters in diameter) of dense pyroclastic flow material torn from the top of the caldera wall and found more than 2 kilometers downstream in the southern outflow canyon, support a catastrophic flood event. During the lake-draining event, Turquoise cone and Mt. Finch acted as earthen dams, preserving the lakes in the northern portion of the caldera.

At least 15 small cinder cones have formed since the caldera-forming eruption (fig. 5). The majority are in the northern half of the caldera, although a few are scattered along the northern caldera wall and outside of the caldera rim to the east and northwest. Two large eruptions from cinder cones have occurred outside the caldera. One occurred about 3 kilometers northwest of the caldera from a fissure and formed a curvilinear ridge of cinders. The other occurred about 1 kilometer southeast of the caldera and formed one small and two large cinder cones and produced a 9-kilometer-long, 1-kilometer-wide, 15-meter-thick lava flow that extends nearly to the Pacific Ocean.

Phreatomagmatic eruptions have occurred frequently at Fisher volcano, especially since the caldera-forming eruption and the formation of a large caldera lake. There are at least three maar craters in the caldera, and ample geologic evidence exists for additional maar-type vents. A low wall along the length of Turquoise lake's eastern shore is composed of a series of dipping surge deposits, indicating repeated phreatomagmatic activity. Thick deposits of accretionary-lapilli-rich eruptive debris cover the highest points of all structures in the eastern caldera and fill valleys near maar craters. Outside the caldera, similar deposits are more than 100 meters thick, indicating either extremely energetic eruptions from vents inside the caldera or undiscovered vents outside the caldera walls. Overall, an area of 450 square kilometers has been affected by deposits from phreatomagmatic eruptions.

Fisher volcano has experienced significant modification of its caldera since it formed about 9,400 years ago. Outward migration of caldera walls by slope failure has widened the caldera and left thick accumulations of debris along the base of the walls. This process continues at present, and vigorous rockfall activity is common.

\section{THE HISTORICAL RECORD OF VOLCANIC ERUPTIONS}

Although Native Aleuts probably observed eruptions at Fisher volcano for thousands of years, the earliest written records date only to the time of Russian exploration and colonization in the 18th and 19th centuries. The remote location of Fisher meant that until World War II individuals on passing ships or airplanes at times when the weather was clear made most observations of volcanic eruptions. Such records probably underestimate the actual number of eruptions.

Only three reports of historic eruptive activity have been made for Fisher volcano - in 1795, 1826, and 1830 - and none of those have been verified (Grewingk, 1850; Coats, 1950; Simkin and Siebert, 1994). Frequent activity of the adjacent Shishaldin and Westdahl volcanoes could have resulted in erroneous reports concerning Fisher, either that reported eruptions of Fisher were actually from one of the 

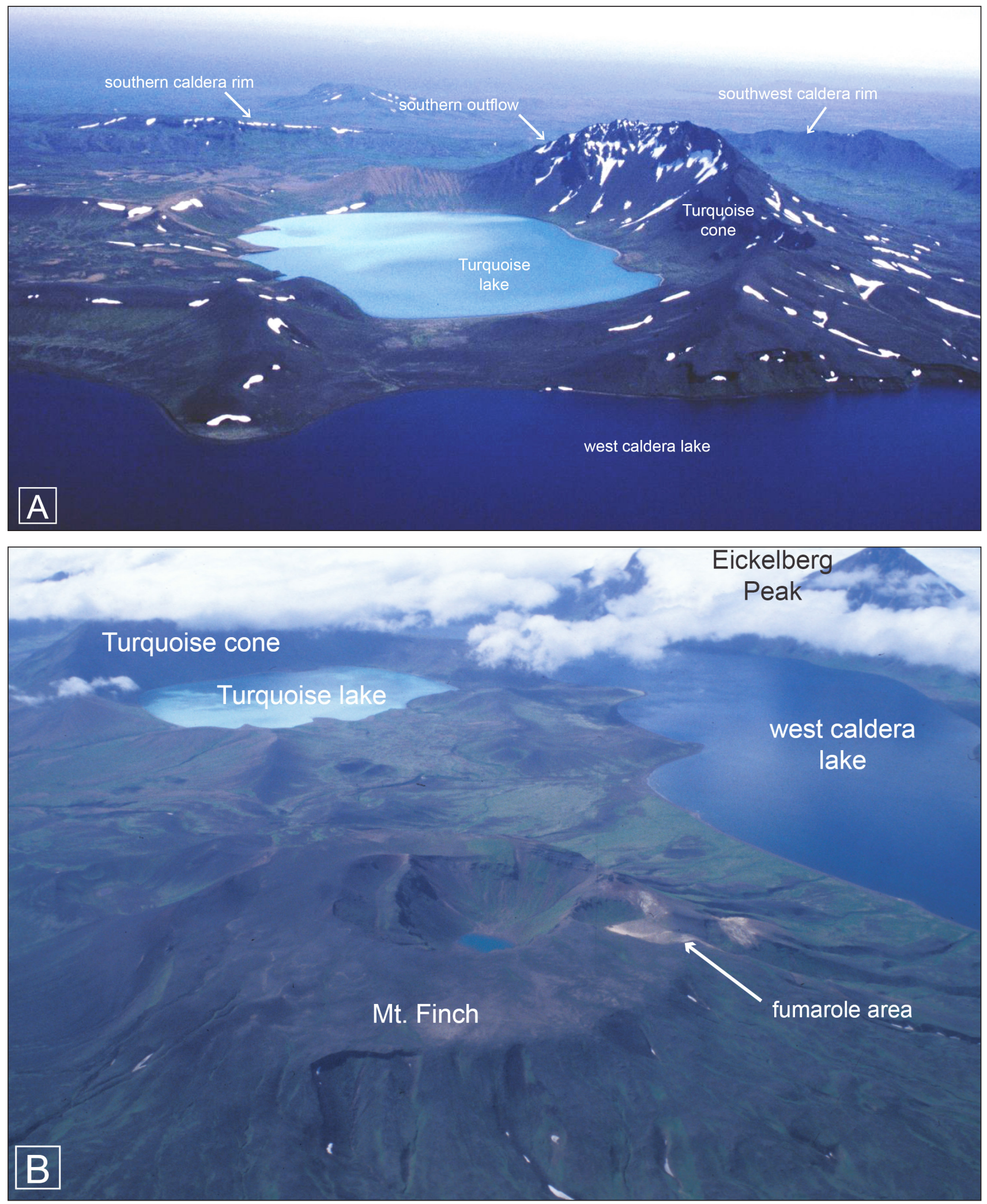

Figure 7. Photographs of Turquoise cone and Mt. Finch. A. Turquoise cone, looking to the south. In the foreground is the West caldera lake, and the snow-capped ridge in the middle distance is the southern caldera rim. The collapse of Turquoise cone removed more than half of the original stratocone. Photo: J. Gardner, 2000. B. Looking toward the west, Mt. Finch is visible in the foreground with Turquoise lake in the background. The collapse of Mt. Finch formed the small conical depression in its summit. The light-colored areas are patches of hydrothermal alteration from fumarolic activity. Photo: P. Stelling, 2000. 


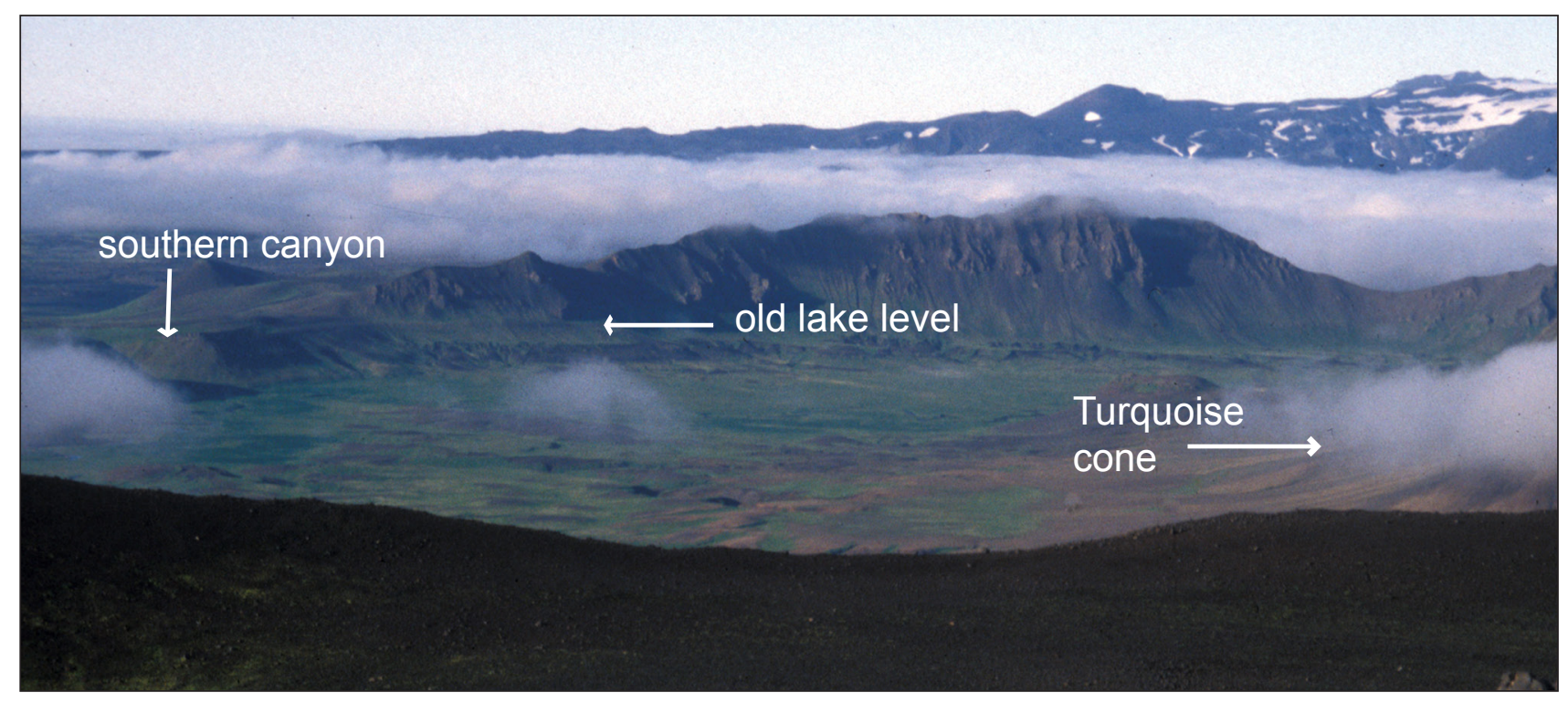

Figure 8. Photograph of the southwestern corner of Fisher caldera as seen from the summit of Mt. Finch. This canyon was carved by water surging over the caldera wall after an intra-caldera eruption near Turquoise cone created a tsunami in the caldera lake. Lakeshore deposits inside the caldera wall indicate the lake level prior to catastrophic draining. Photo: P. Stelling, 2000.

Figure 9. Surge deposits in the caldera east of Mt. Finch. These deposits were formed during a violent phreatomagmatic eruption caused by the interaction of magma and water. Photo: P. Stelling, 2000.

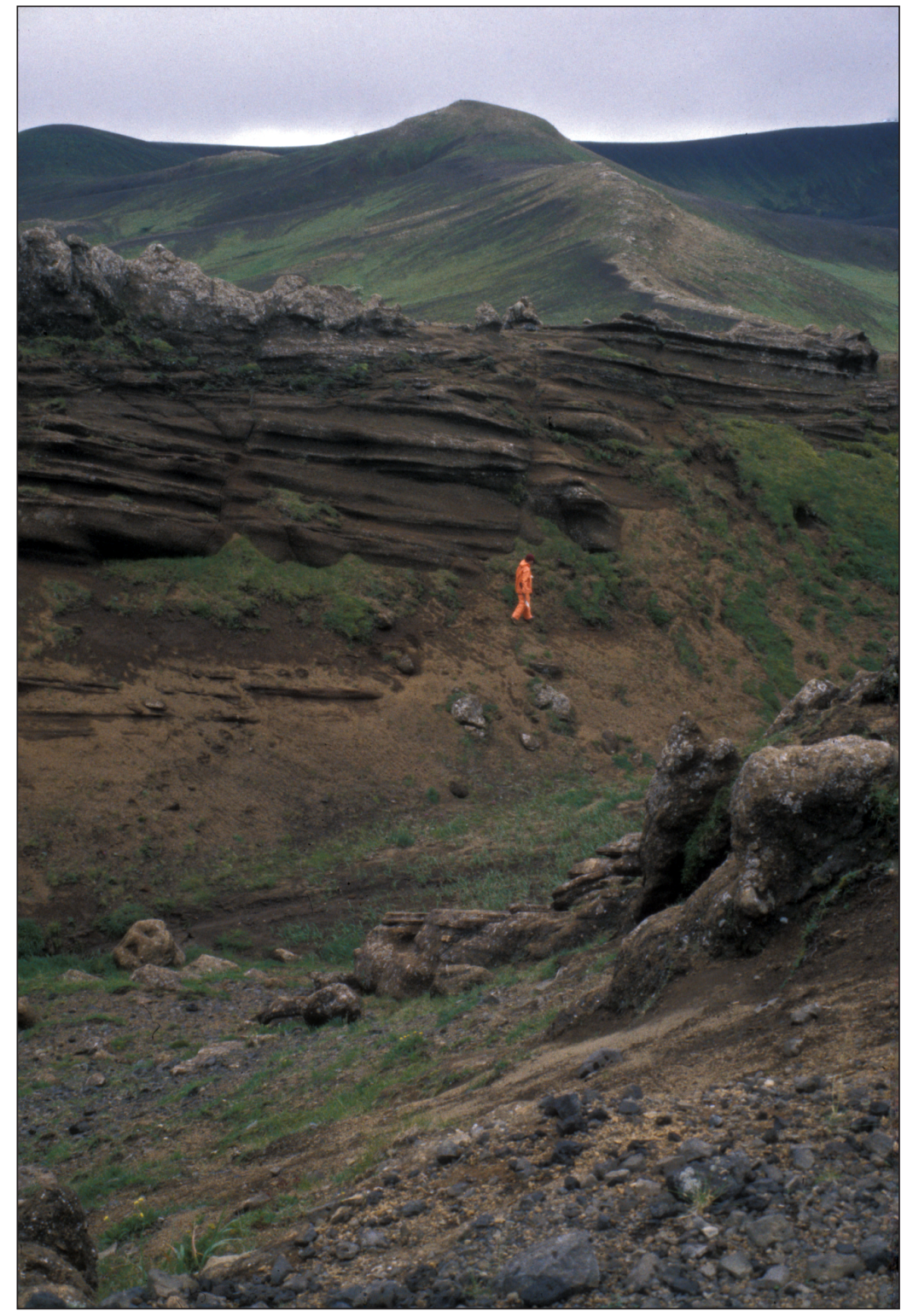


other volcanoes or vice versa. The 1830 eruption is probably more accurately attributed to Westdahl volcano as the original report reads, "1830: Volcanic eruption on the SW end of Unimak Island in August" (Grewingk, 1850). Whichever reports are accurate, a single, thin layer of scoriaceous ash in the modern soil surrounding Mt. Finch indicates that there has been only a single eruption at Fisher volcano in historic time and that Mt. Finch was the likely source (fig. 10).

Several hot springs are present in the southwestern part of the caldera, with temperatures exceeding $44^{\circ} \mathrm{C}\left(111^{\circ} \mathrm{F}\right)$

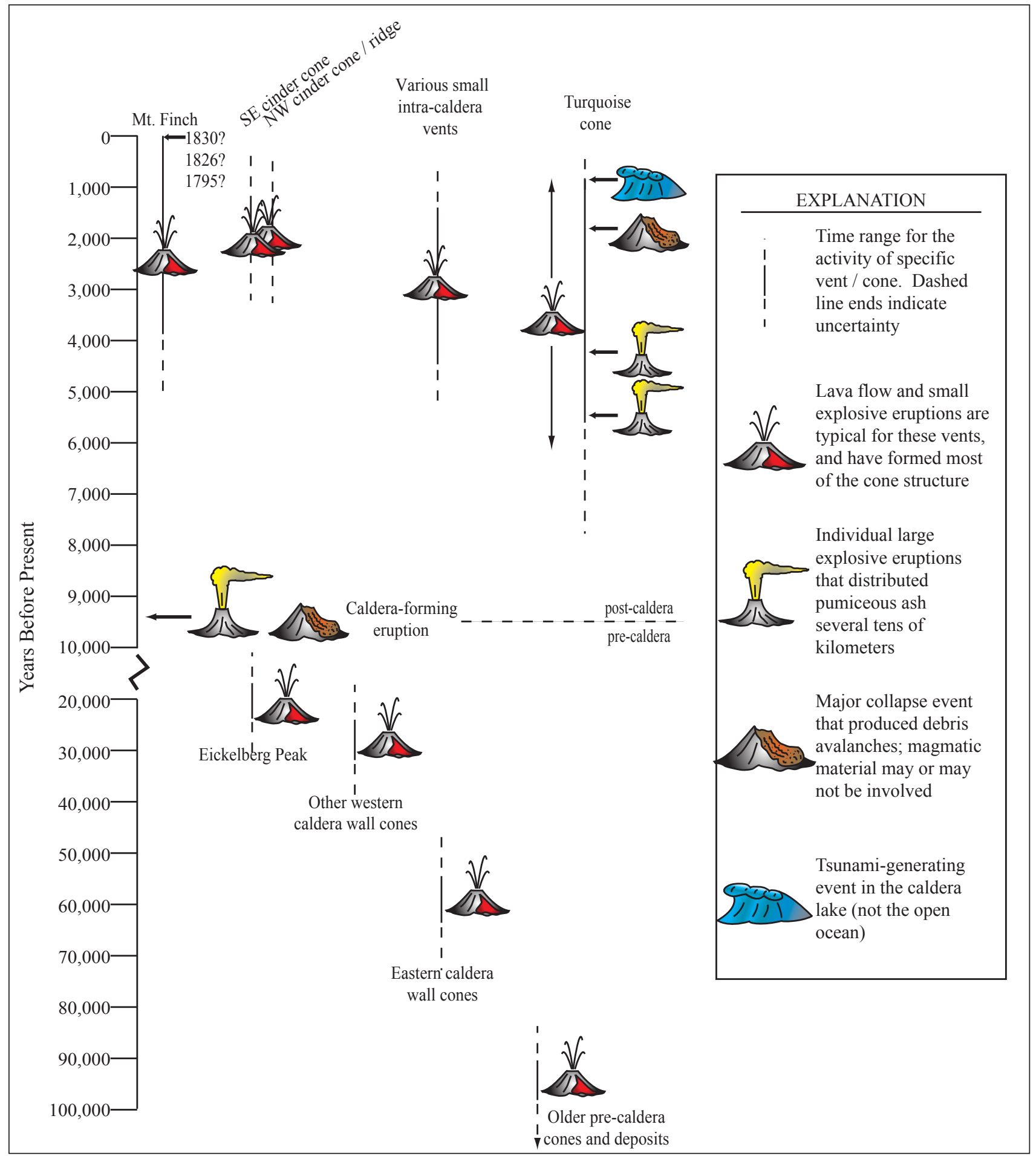

Figure 10. Eruption history of Fisher volcano, based on geologic mapping (Stelling and others, 2005). Note the change in time scale between pre-and post-caldera. The three dates listed for the most recent eruption (with question marks) indicate ambiguity over the actual date; deposits of only one recent eruption are observed at Fisher, most likely from Mt. Finch. 
in 1999. Turquoise lake is warmer than surrounding bodies of water, has active upwelling of warm water (creating the distinctive color of the lake), and frequently emits strong sulfur smells. Periodic upwelling in the western caldera lake has also been observed.

\section{POTENTIALLY HAZARDOUS VOLCANIC PHENOMENA AT FISHER VOLCANO}

The range of eruption styles of Fisher volcano presents a wide variety of potential hazards (Blong, 1984; Scott, 1989; Blong, 1996), although the lack of infrastructure surrounding Fisher volcano and its remote location limit the exposure of people and property to substantial risk. It is unlikely that anyone would be exposed to significant hazard from a non-explosive or small explosive eruption of Fisher volcano unless adventurers were traveling in the area or boats were near the coast. A larger eruption of Fisher volcano is more likely to impact people and transportation. Fisher volcano is positioned beneath air traffic corridors crossing the North Pacific Ocean, and large numbers of passenger and freight jets pass over Fisher and nearby areas of the North Pacific Ocean daily. Although modern equipment and monitoring techniques are capable of determining changes in a volcano that could precede an eruption, predicting the precise size and style of future volcanic eruptions remains elusive.

This section discusses the potential hazards associated with future eruptions of Fisher volcano (fig. 11). All hazards are more dangerous for locations closer to the vent, and the degree of risk gradually decreases with distance from the vent area. Some hazards are restricted to the near-vent area, while others can affect areas 20 kilometers or more from the eruption center. The type of volcanic hazards present during an eruption can change with eruptive style or weather conditions. Volcanic eruptions are dynamic and can change, start, or stop at any time, independent of other phenomena. Small, localized eruptions can rapidly become large, energetic volcanic eruptions with significantly different hazards. Multiple types of hazards can occur simultaneously, and the areas at risk during an eruption will vary depending on the magnitude and style of the eruption, as well as local conditions.

The extents of hazard zones presented in this report are approximate due to inadequate topographic base maps and the preliminary nature of our geologic investigation. Additionally, because many hazards can be influenced by local topography, the risk from a hazard can vary within specific hazard zones. For example, floods and lahars can devastate the bottom of a valley, whereas the top of an adjacent hill could be untouched.

The sizes and distributions of hazard zones on the hazard map are based on our geologic investigations and mapping, during which we have determined the actual distribution of older volcanic deposits produced during prehistoric and historical eruptions. Although historical activity has been limited to a few small explosive eruptions, prehistoric eruptions of Fisher volcano have produced ashfall, pyroclastic flows and surges, lava flows, debris avalanches, mudflows, and floods that repeatedly impacted areas near the volcano, and will likely do so in the future. Volcanic ash clouds, ash fallout, and pyroclastic flows and surges have occasionally reached areas more than 20 kilometers from the volcano. Deposits from eruptions during the last 9,000 years provide a reasonable model for evaluating the likely eruptive style and extent of erupted deposits that could occur during similar eruptions in the future. Much larger eruptions that occurred during the last 10,000 years (such as the caldera-forming eruption) form the basis for evaluating volcanic hazards that might accompany very large but infrequent eruptions of Fisher volcano.

\section{PRINCIPAL VOLCANIC HAZARDS}

\section{Volcanic Ash Clouds}

The principal hazard from future eruptions of Fisher and most volcanoes in the Aleutian arc is the production of volcanic ash clouds that extend high into the atmosphere where they can enter the path of passenger jets and other aircraft and cause potentially catastrophic damage to jet engines, avionics, and other equipment (fig. 12).

During the last 9,000 years Fisher volcano has experienced repeated explosive eruptions, sending ash at least as far as Cold Bay (120 kilometers east) in two cases. Superheated gas released in an explosive volcanic eruption can propel ash to great heights. In the case of extremely large eruptions, ash columns can ascend convectively to altitudes of 40 kilometers (25 miles or 130,000 feet) above sea level or higher. Once aloft, the millions of microscopic- to centimeter-sized particles of pulverized volcanic rock in the ash cloud are carried by the prevailing winds, which can change direction with altitude. Ash clouds can maintain their buoyancy and integrity for days to weeks while traveling through the atmosphere for distances of hundreds to thousands of kilometers, depending on the size of the eruption and the prevailing wind patterns. Aircraft encountering ash clouds can be subjected to serious consequences. Jet engines, windows, air intakes, electronics, and other parts of aircraft can be damaged or destroyed by the physical and/or geochemical properties of volcanic glass and other material carried by ash clouds (Casadevall, 1994; Swanson and Begét, 1994).

Although no airplanes have been affected by an eruption of Fisher volcano, recent activity from other Alaska volcanoes can be used to illustrate potential hazards presented by future, perhaps larger, eruptions of Fisher volcano. The 1976 eruption of Augustine Volcano generated ash clouds that reached 12 kilometers (39,000 feet) above sea level before drifting eastward. The ash clouds were tracked and observed as far south as Arizona and as far east as Virginia. During another eruption of Augustine Volcano in 1986, four separate ash clouds ascended at least as high as 12 kilometers. One jet aircraft flew through an ash cloud, and air traffic was disrupted at numerous Alaska airports for several weeks (Waythomas and Waitt, 1998). In all, five jet aircraft have 


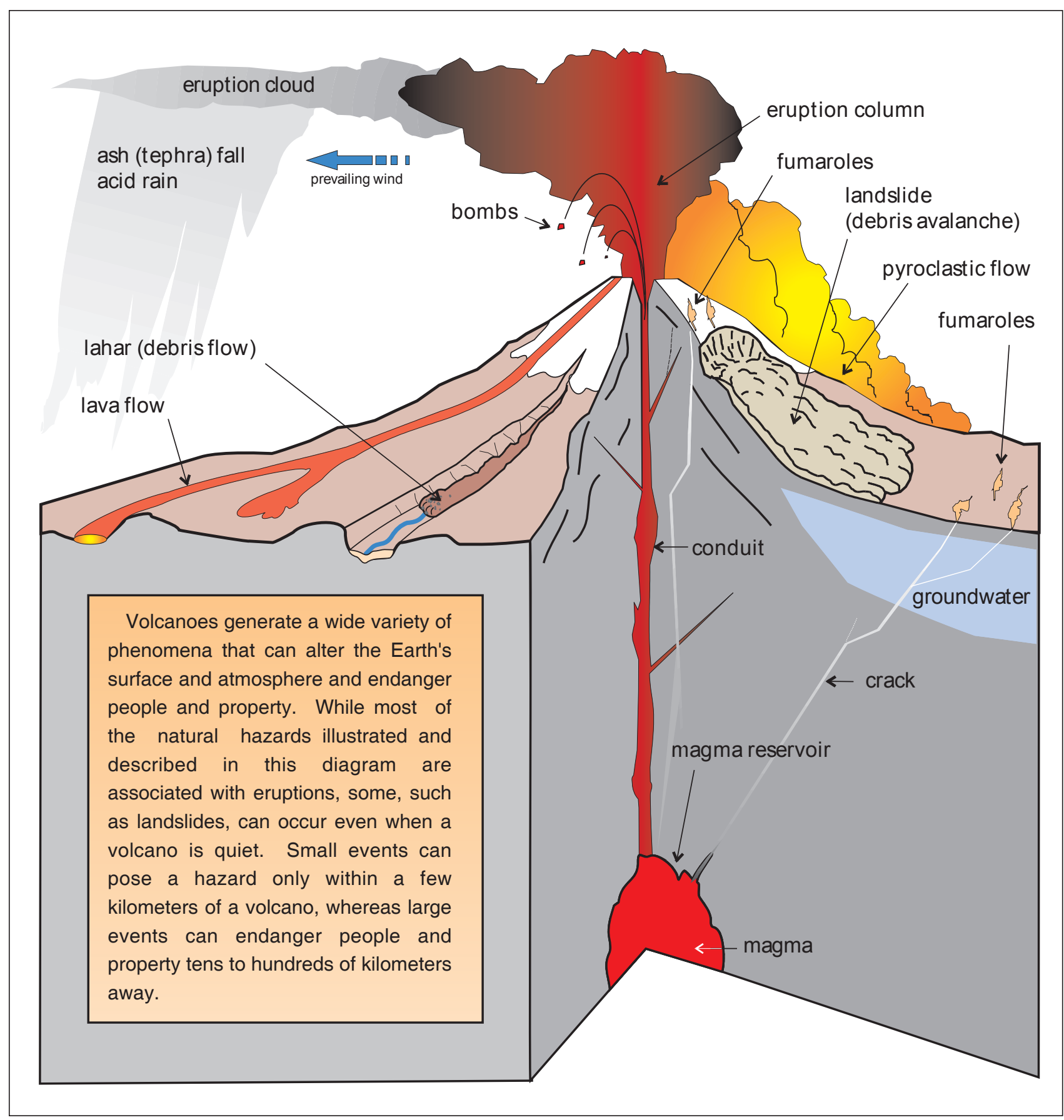

Figure 11. Simplified sketch of a stratovolcano and associated hazardous phenomena resulting from typical eruptions. Depicted phenomena do not necessarily occur simultaneously during a particular eruption. From U.S. Geological Survey Fact Sheet 002-97 (Myers and others, 1997).

flown through volcanic ash clouds from Alaskan volcanoes, each sustaining abrasion damage on windshields, wings, landing gear, and other parts of the planes resulting from interaction with volcanic ash particles (Casadevall, 1994; Waythomas and others, 1998; Begét and others, 2003).

In 1989-90, Redoubt Volcano sent several ash clouds to at least 12 kilometers above sea level. On December 15, 1989, a Boeing 747 carrying 231 passengers on its maiden flight flew into an ash cloud 240 kilometers northeast of Anchorage International Airport. Abrasion blackened all windows, blinding the flight crew, and power was lost in all four jet engines. The plane lost more than 3,000 meters ( $\sim 10,000$ feet) of elevation before the pilots were able to restart two of the engines (Casadevall, 1994). After landing, it was determined the airplane had suffered about $\$ 80$ million in damage (Brantley, 1990). About two days later the 


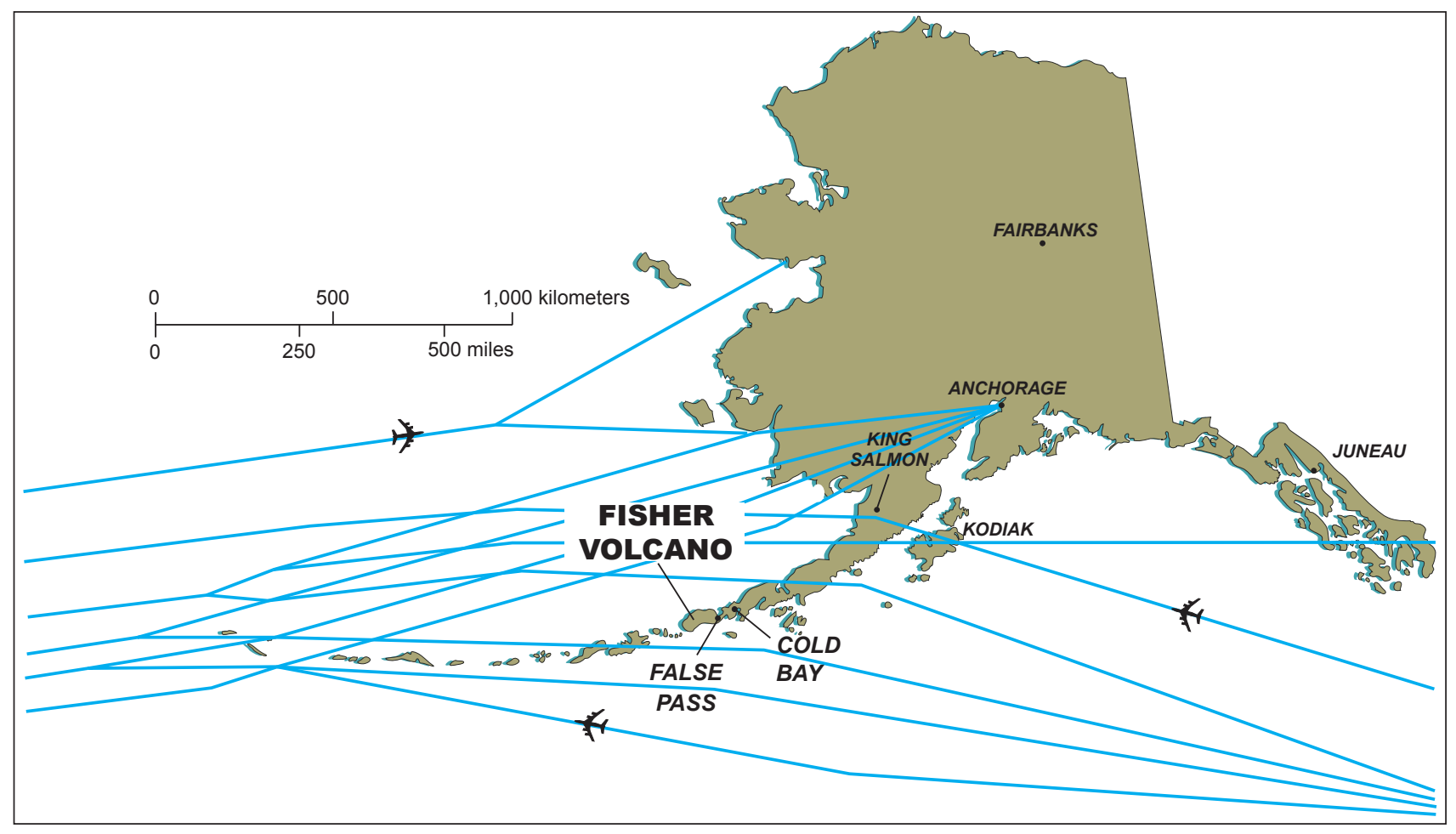

Figure 12. Flight paths of commercial freight and passenger aircraft crossing the North Pacific. Future explosive eruptions of Fisher volcano could send ash as high as 10,000 to 20,000 meters ( 30,000 to 65,000 feet) into the atmosphere, causing disruption of normal trans-Pacific flight schedules.

Redoubt ash cloud had drifted more than 5,400 kilometers to the southeast, where two jets encountered it over west Texas. One of these jets suffered a transient engine stoppage, while the other jet's wings were abraded (Waythomas and others, 1998).

Hazards presented by future explosive eruptions of Fisher volcano depend on the characteristics and magnitude of the eruption, including the altitude and ascent rate of the ash cloud; the wind direction and velocity (and changes in the wind at different atmospheric levels); the total amount of sulfur and other gases; and the concentration, size, and geochemistry of particles in the ash cloud. The far-field distribution and transport of ash clouds will be primarily controlled by meteorological conditions at the time of the eruption, especially wind speed and direction (fig. 13). Because the predominant wind direction at Fisher Caldera is from the west, large eruptions of Fisher are likely to produce ash clouds that will travel east and affect air travel and operations at the Cold Bay airport, and potentially create hazards to air traffic operating in other areas of Aleutian air space, including the North Pacific Ocean (fig. 12). Deposits several centimeters thick from Fisher's caldera-forming eruption and from two eruptions believed to be from the collapse of Turquoise cone are present adjacent to the Cold Bay airport, indicating that volcanic ash clouds from Fisher could pose an infrequent but potentially substantial hazard to air traffic in the area.

\section{Volcanic Ash and Bomb Fallout}

During explosive eruptions, large volcanic bombs, ash, pumice, and rock debris are likely to be thrown into the air and rain out ballistically around the volcano with larger particles landing closer to the vent. Large volcanic bombs typically fall no more than a few kilometers from the vent, although very energetic explosive eruptions can send rock fragments as far away as 5 kilometers or more. The majority of Unimak Island, particularly the area around Fisher volcano, is uninhabited, thus the risk from ballistic fallout of volcanic material is low except to humans and low-flying aircraft that might come near the volcano during an eruption.

Although the fall zone of larger volcanic bombs is restricted to near-vent areas, finer-grained volcanic ash particles will be ejected greater distances and can form a transient ash cloud, with ash falling out as it drifts away from the eruptive center. Thus, volcanic ash can affect areas tens, hundreds, or even thousands of kilometers away from the eruption (fig. 14). During such an event, visibility could be reduced as the sky darkens, interrupting all types of surface and air transportation.

Even relatively thin accumulations (1 to 2 millimeters) of ash can affect a wide range of mechanical and electrical systems; thus, ash accumulation could be an important consideration for the nearby communities of False Pass or Akutan if an unusually large eruption were to occur. Any machinery with an air intake system can become clogged and 


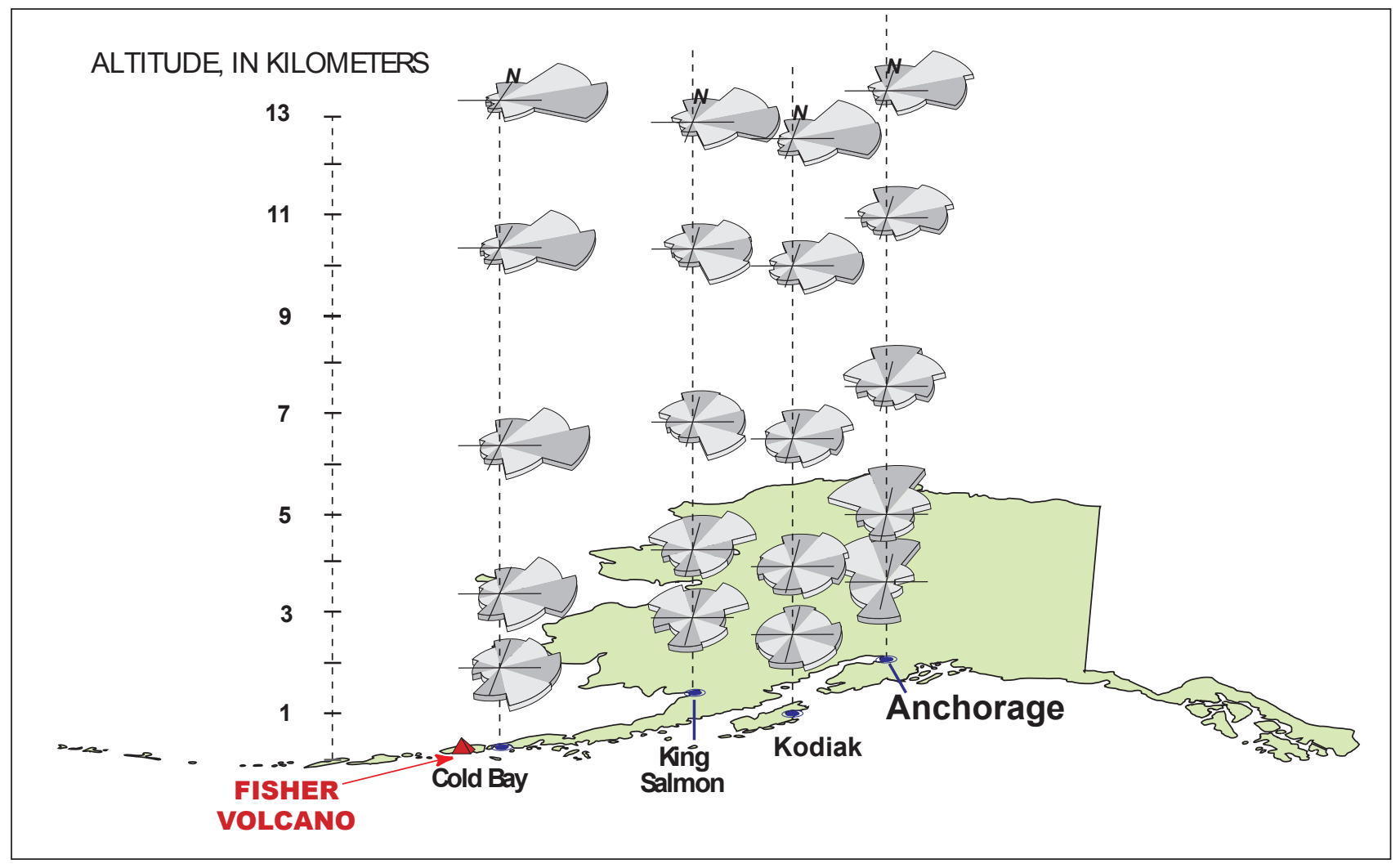

Figure 13. Annual average wind direction over southwestern Alaska. Volcanic ash during future eruptions of Fisher volcano will drift with the wind, most likely toward the northeast, east, or southeast. The lengths of the sections on the wind rose diagrams are proportional to wind frequency determined by annual percent. Original data are from the National Climatic Data Center, National Oceanic and Atmospheric Administration.

damaged, including internal-combustion engines, cooling systems, and others. Vital equipment, such as that in power plants, water pumping or treatment facilities, electrical generation systems, and factories, all of which are present at Akutan, could be damaged. Telephone and other communications equipment can also be short circuited (Blong, 1984; Scott, 1989; Blong, 1996).

If future eruptions at Fisher Caldera are similar in size to the eruptions of only the last 200 years, the areas most likely to be affected by significant ashfall will be restricted to the area within the caldera, the flanks of the volcano, and nearby areas of Unimak Island, and are unlikely to create significant risk to people. Geologic studies show, however, that several more powerful eruptions have occurred during the last 9,400 years. Pumice deposits from the caldera-forming eruption are as thick as 1,000 centimeters (10 meters) on the caldera rim, have been identified several hundred kilometers away, and could have traveled several thousand kilometers. A recurrence of a very large eruption at Fisher might result in accumulations of ash as thick as several centimeters or more at distances as far or farther than Cold Bay and trace accumulations of ash thousands of kilometers away (fig. 14).

\section{Pyroclastic Flows and Surges}

Pyroclastic flows and surges are among the most dangerous of all volcanic phenomena. Pyroclastic flows are hot $\left(\sim 800^{\circ} \mathrm{C}\right.$, or $\left.\sim 1,500^{\circ} \mathrm{F}\right)$ mixtures of volcanic rock debris and gas that move down slope under the influence of gravity, resembling a snow avalanche. They typically consist of coarse debris in a basal flow zone and an accompanying dilute, hot dust cloud above (fig. 11). Pyroclastic flows can form when ash and hot rock debris are explosively ejected and collapse onto the volcano's flanks, or when part of a growing volcanic dome collapses into rock fragments. Pyroclastic surges are similar to pyroclastic flows but lack the coarse basal flow zone, and instead consist primarily of dilute mixtures of relatively fine rock fragments and ash suspended in turbulent gas. Surges can be generated by large volcanic explosions, violent phreatomagmatic eruptions, or as a separate phase associated with simultaneous pyroclastic flows.

Pyroclastic flows and surges constitute an especially severe and unpredictable hazard to humans because of their speed, mobility, and high temperatures (Baxter and others, 1998). They can travel considerable distances, burying and incinerating any person, object, or structure they encounter. Even the slightest contact with distal ash clouds at the margin 


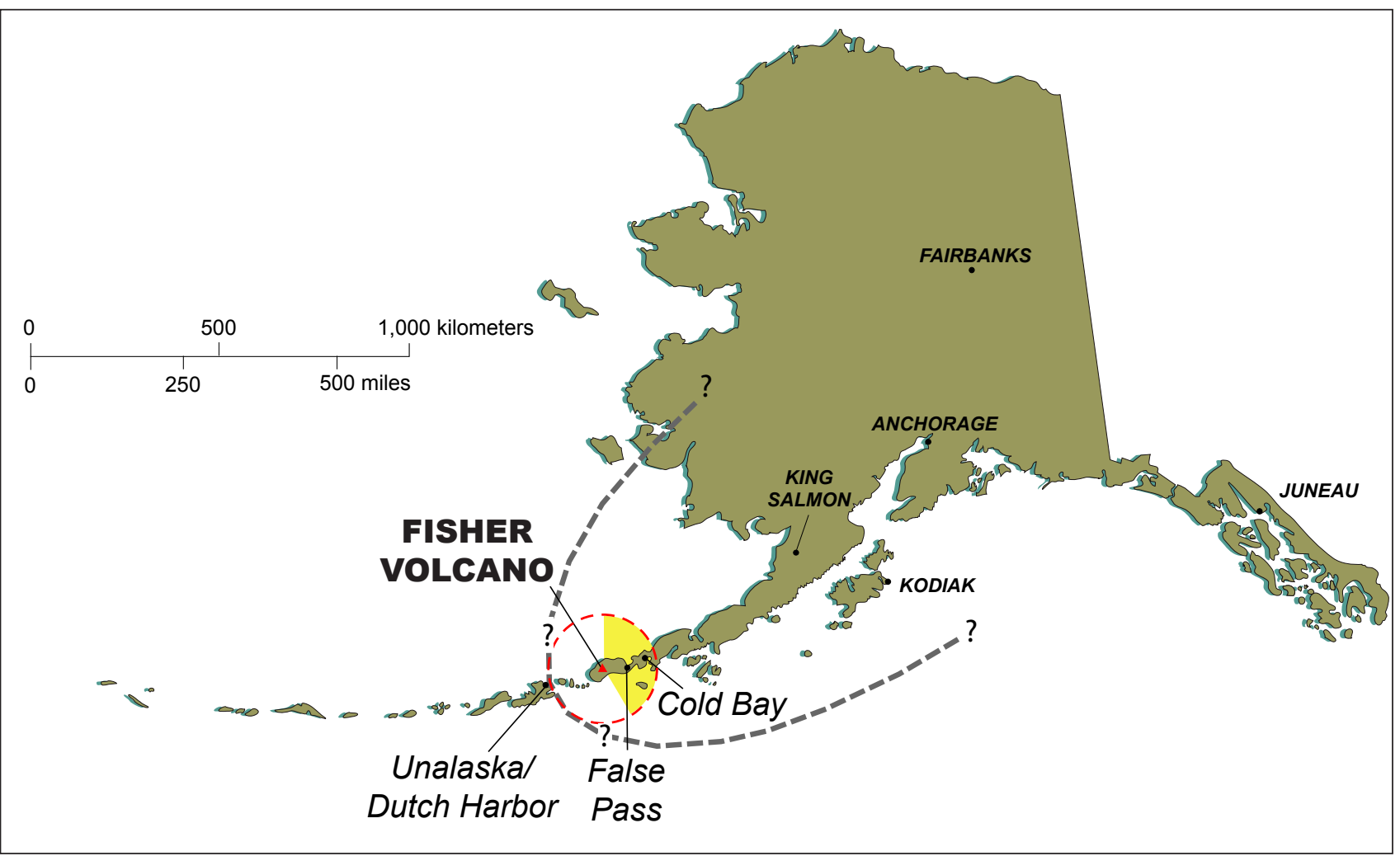

Figure 14. Areas that could be impacted by ashfall during an eruption of Fisher volcano. The dashed red circle indicates areas in Alaska within $\sim 150 \mathrm{~km}$ of Fisher that could be affected by ash fallout during a typical eruption of Fisher volcano. The exact area of ash fallout will depend on weather conditions, wind directions, and the location of the eruptive vent, but is likely to affect areas mainly east of the volcano (yellow shaded area). Ashfall during small eruptions will be restricted to the immediate vicinity of the volcano and surrounding parts of Unimak Island. A very large eruption at Fisher could result in accumulations of ash as thick as several centimeters or more at distances as far as Cold Bay or farther, and trace accumulations of ash thousands of kilometers away (outer gray dashed line and beyond).

of surges or pyroclastic flow can be hazardous, as the dilute clouds can burn the skin, throat and lungs, as well as cause asphyxiation. Also, high-velocity ash clouds and surges often occur as very powerful blasts of wind, which can blast down buildings and carry sand-sized and larger rock fragments that can cause injury by impact as well as by their intense heat (Baxter and others, 1998).

Geologic studies of the source and extent of pyroclastic flow and surge deposits erupted from Fisher volcano indicate that pyroclastic surge deposits have affected nearly every area in the caldera, particularly the eastern half. The majority of these deposits are the result of phreatomagmatic eruptions from at least three different vents during the last 2,000 years. Surge deposits from these eruptions cap many of the hilltops in the caldera. During several eruptions, explosions were large enough to send surges beyond the caldera rim and across the flanks of the volcano. Pyroclastic surge deposits about 100 meters thick lie approximately 1 kilometer outside the northwestern caldera rim. The upper 30 meters of this deposit become increasingly enriched in scoria cinders, suggesting the eruption began as an extremely energetic phreatomagmatic eruption producing violent surges and transitioned to an explosive magmatic eruption. The likely source of this eruption is about 2.5 kilometers from this deposit, a large, intracaldera cinder cone between the western caldera lake shore and the northwestern caldera rim, about 4 kilometers east-northeast of Eickelberg Peak (fig. 5). Nearly all areas within 10 kilometers from the caldera rim have been affected by pyroclastic surges since the caldera-forming eruption; however, no surge deposits have been observed beyond this distance. Therefore, the hazard extent for pyroclastic surges at Fisher Caldera has been determined to be 10 kilometers (fig. 15).

Exceptionally large and highly mobile pyroclastic flows and surges could occur at Fisher if eruptions as large as the caldera-forming eruption were to recur. Such pyroclastic flows could travel up to 40 kilometers from the volcano, potentially affecting every flank of Fisher volcano from the caldera to the coast (fig. 15). Deposits from the pyroclastic flows generated during the caldera-forming eruption exceed 50 meters in thickness on top of the 500-meter-high Tugamak Range 15 kilometers to the north of Fisher Caldera. Similar deposits are more than 20 meters thick on the far side of the Tugamak Range at the coast, suggesting a significant amount 


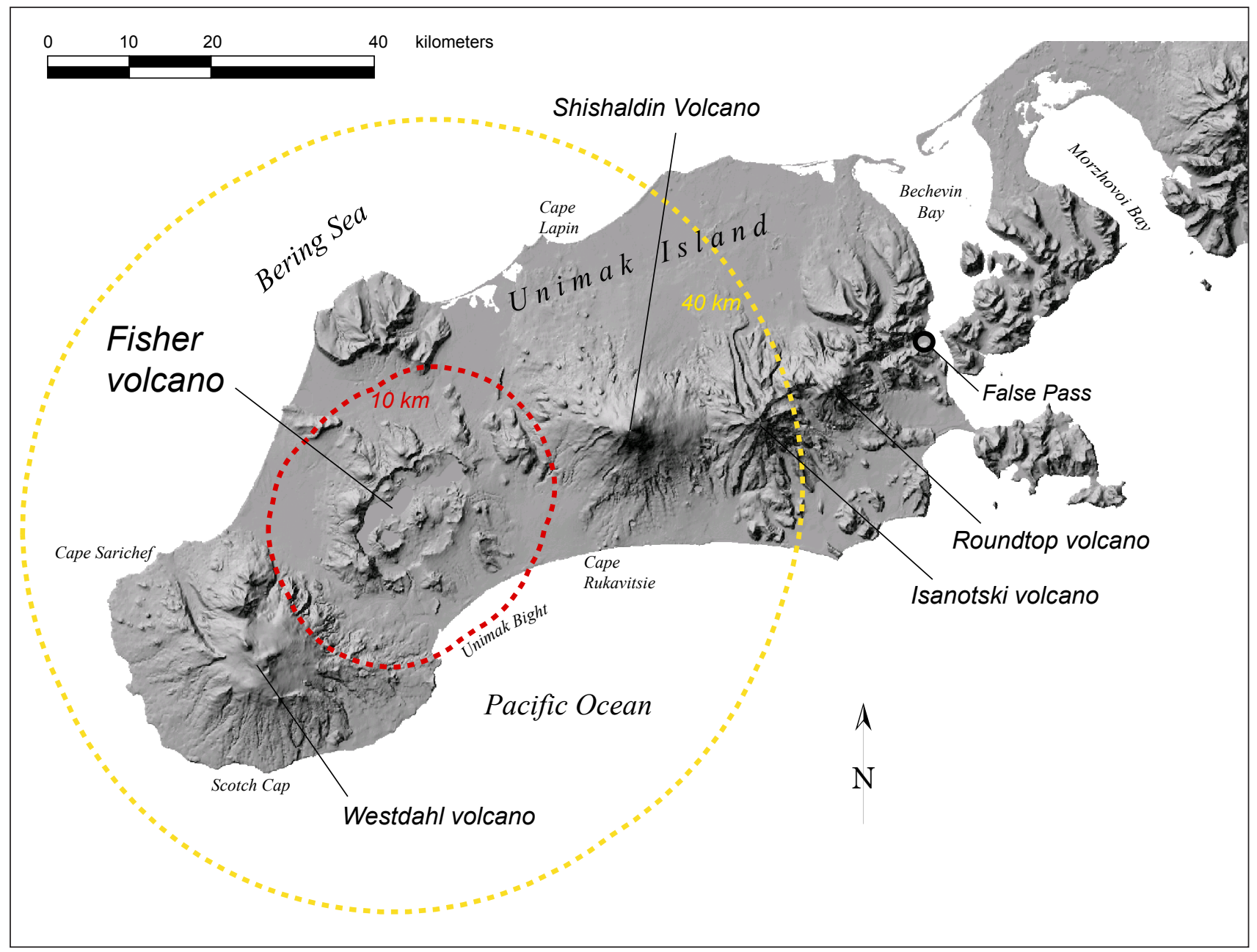

Figure 15. Areas that could be affected by pyroclastic flows and surges during typical small to moderate future eruptions of Fisher volcano are shown by the inner, red-dashed 10 kilometer circle; the maximum extent of pyroclastic flows during a very large eruption similar to caldera-forming events that occurred $\sim 9,400$ years ago are shown by the outer, yellow-dashed, 40 kilometer circle. Such large events occur very rarely at Fisher volcano.

of volcanic rock debris was sent into the Bering Sea. Deposits 30 kilometers from the vent are greater than 3 meters thick; deposits 40 kilometers away, north of Isanotski volcano, are up to 18 centimeters thick. Based on this evidence, the maximum hazard zone extent for pyroclastic flows surrounding the caldera is set at 40 kilometers (fig. 15). Pyroclastic flows have been channeled down valleys and low-lying areas along the floors of valleys in and around Fisher volcano, and these areas should be considered particularly dangerous during explosive eruptions.

It is important to note that pyroclastic flows and surges can travel across water. This phenomena has been observed repeatedly during the volcanic eruptions that began in 1997 on the island of Montserrat in the Caribbean Sea (Cole and others, 2002). During the large caldera-forming eruption of Krakatau Volcano in 1883, pyroclastic flows produced casualties on land in southern Sumatra after traveling more than 40 kilometers over water (Carey and others, 1996). Although it is probable that a significant volume of pyroclastic flow material from the Fisher caldera-forming eruption lies offshore in the Bering Sea, our investigation has not extended offshore of Unimak Island and we have not been able to quantify the over-water distance traveled by the pyroclastic flow, or determine how much of the deposit lies offshore. In the highly unlikely event of a near-future recurrence of an eruptive event similar to Fisher volcano's caldera-forming eruption that occurred $\sim 9,400$ years ago, open water will not offer protection to vessels at sea. Fishing boats and vessels should maintain a safe distance from the coastline during the course of an explosive eruption.

\section{Lava Flows and Domes}

Non-explosive eruptions of molten rock can form local, steep-sided lava domes, or lava flows that move downslope in long, stream-like flows, or spread out, forming fans of lava.

During the last $\sim 9,400$ years many lava flows have erupted from several different vents inside and outside of 
the caldera, with Mt. Finch being the site of the most recent lava eruptions. Although most lava eruptions have occurred inside the caldera, several lava flows have erupted at sites outside the caldera (fig. 5), including one from a small cinder cone southeast of the caldera; that flow traveled 8 kilometers and nearly reached the Pacific Ocean. Although no such eruptions have occurred in historical time, lava flow hazards exist inside and outside the caldera.

Lava flows like those erupted at Fisher tend to move slowly downhill at velocities of only a few meters to tens of meters an hour, and humans can typically escape an advancing lava flow by walking away. Additional hazards from lava flows exist near active vents or in low-lying areas where lava can accumulate and pond. Lava flows can also create floods by melting snow or damming streams. The western lake in the caldera is dammed in part by a large lava flow from Turquoise cone. Lava flows entering bodies of water can create steam plumes that can scald anything in its immediate vicinity.

During an eruption of viscous lava, steep-sided lava domes or flow fronts can form. These features are prone to collapse, which can lead to avalanches of hot debris, pyroclastic flows and surges, ballistic fallout, and ash clouds. Although there is no evidence of this type of volcanic activity at Fisher in the past, if very viscous lava were to erupt from Fisher in the future, such features and eruptive styles are possible.

Because the majority of post-caldera activity at Fisher volcano has occurred inside the caldera, future lava eruptions are also likely to be confined to the caldera floor. The hazard zone for lava eruptions thus includes the entire floor of the caldera. However, future lava eruptions could also occur on the outer flanks of Fisher volcano. Such eruptions can produce lava flows during the formation of a new cinder cone (volcanic ejecta pile), and could occur in areas with little to no previous eruptive activity. Because the area around Fisher volcano is uninhabited and unlikely to be developed, lava-flow eruptions at Fisher pose little hazard to humans.

\section{Lahars and Floods}

Floods and lahars (volcanic mudflows) can be produced during volcanic eruptions by melting glacier ice and snow, or by releasing lake water dammed within the caldera. Floods are water-rich with relatively low concentrations of entrained rock material, whereas lahars typically consist of concentrated muddy suspensions of boulders, sand, and silt, often with the consistency of wet cement. Floods and lahars can travel up to 20 kilometers or more downvalley at speeds of 10 to 30 kilometers per hour.

Lahars and floods are very dynamic processes, and can be generated suddenly and without warning. They are typically restricted to valleys and can flow considerable distances from their source, sometimes surprising people who believe they are a safe distance from the eruptive activity. Lahars and floods can form when eruptive events, such as pyroclastic flows or surges, rapidly melt snow and/or ice, generating large amounts of water that can travel rapidly downvalley. Floods can quickly transform into lahars as they erode and incorporate ash and other fragmental material on the flanks of volcanoes or in valleys. This process can also transform floods produced by torrential rains into lahars. Lahars can also change character, either by continuing to erode loose material and becoming more viscous, or by depositing much of their sediment load as they flow onto gentler slopes, and becoming a water-rich flood. Lahars often travel downslope along stream valleys, but can be large enough to inundate adjacent floodplains and low-lying areas. Flowing lahars can bury everything in their path under centimeters to meters of sediment.

The heavy snows that cover Fisher Caldera in the winter are potential water sources for eruption-related floods and lahars. If lava flows, pyroclastic flows or surges, or fallout of hot ballistics or ashfall mix with a thick layer of snow, lahars and floods could be initiated on the flanks of the volcano and would likely follow local drainages down to the coast. Floods and lahars produced anywhere in the caldera would be restricted to the caldera floor, and are more likely to inundate low areas such as lake shores and the southwestern portion of the caldera (fig. 16).

Floods and lahars can also be produced when existing lakes are affected by eruptive activity, when new lakes are formed during the course of eruptions, or if earthen dams retaining lake water are damaged. Eruptions beneath any of the three existing lakes in Fisher's caldera, or impacts to the lakes from earthquakes, pyroclastic flows, or other phenomena, could potentially generate floods and lahars (see later section describing volcanic tsunami hazards). A large flood event related to the draining of the caldera lake could have been associated with a phreatomagmatic eruption beneath the caldera lake $\sim 1,500$ years ago (Stelling and others, 2005). If an eruption occurred beneath any of the modern caldera lakes, water could be sent outside the lake and inundate nearby low-lying areas (fig. 16).

Hazards from floods and lahars at Fisher volcano are probably greatest in the southern low-lying areas of the caldera floor and along the southern outflow canyon. These areas would be impacted by eruptive events that affect either winter snowpack or intra-caldera lakes. Collapse of the lava dam that restrains the western caldera lake could drain the lake, sending floodwaters and lahars into the southern portion of the caldera and through the southern outflow canyon. Lahars and floods could then affect other areas outside the caldera. The lowest elevation of the eastern caldera rim is about 20 meters higher than the current lake level. If water in the eastern caldera lake were to be displaced by eruption or other event, a flood wave could wash over the caldera rim and inundate stream valleys and low-lying areas (fig. 16). Floods and lahars could form in other areas outside the caldera, particularly if hot, eruptive material were to mix with thick snow layers. Presently, all valleys radiating away from the caldera are uninhabited and undeveloped, and therefore the risk to people and property is extremely low. Anyone present 


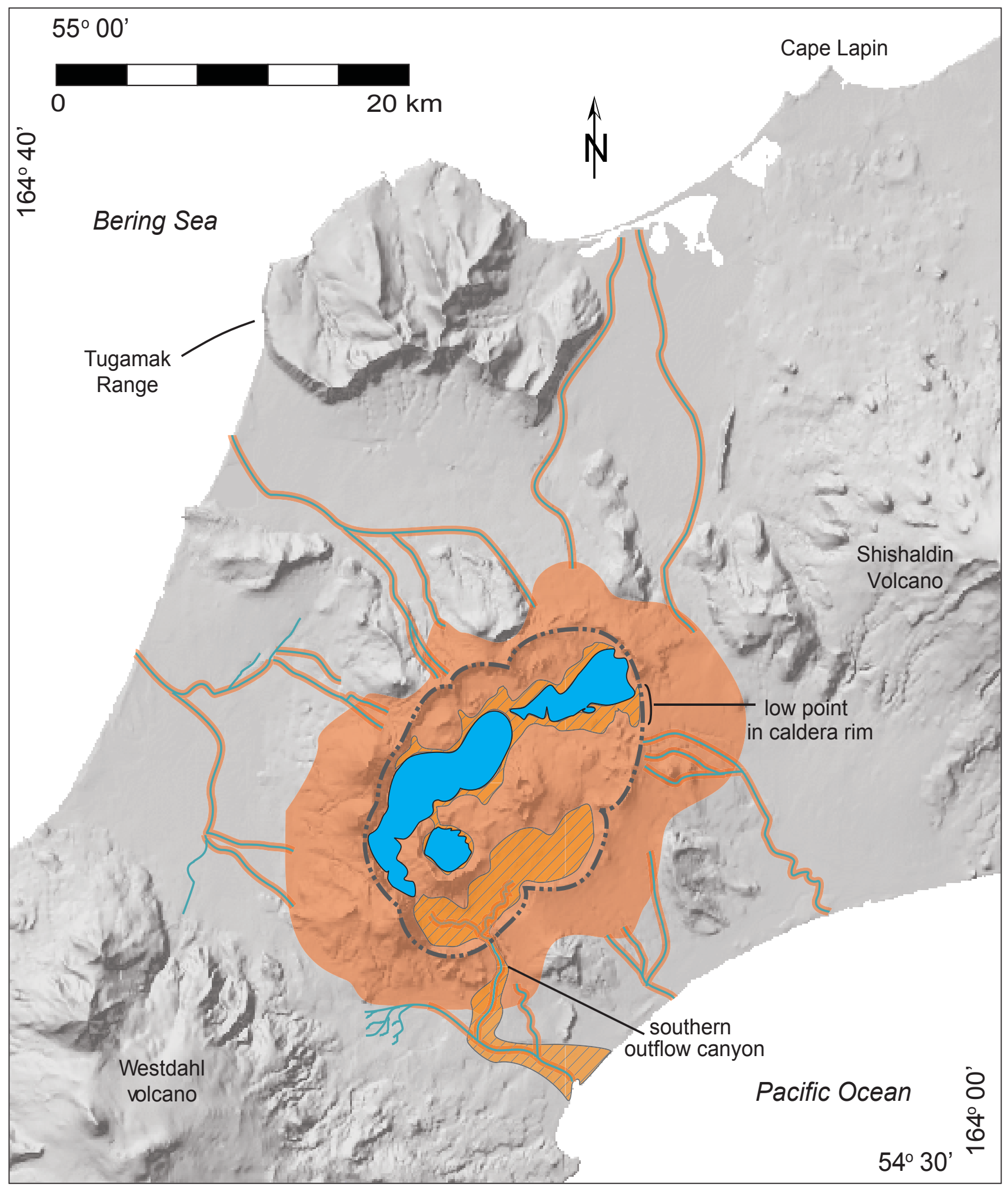

Figure 16. Areas susceptible to flood and lahar hazards. All areas immediately outside the caldera rim, on the caldera floor, and along stream valleys connected to Fisher could be affected by floods or lahars (light shading). Orange hatched areas indicate locations particularly vulnerable to flooding and lahar hazards. 
around the volcano during future eruptions should exercise extreme caution in low-lying areas, especially drainages and floodplains radiating away from the caldera, as floods and lahars generated high on the slopes of the caldera wall or on cones inside the caldera can travel surprisingly quickly. In general, lahar hazards are greater at lower elevations and are slightly diminished at higher elevations. At all elevations, drainages (particularly those with flowing water) represent areas of greater hazard. Floods and lahars can usually be avoided by quickly climbing to high ground.

\section{Rockfalls and Landslides}

The majority of the steep rock walls in the caldera at Fisher volcano are composed of hard, heavily fractured, relatively unstable volcanic material. These areas are prone to rockfalls and landslides; deposits from past events bury the bases of steep cliffs in and around the caldera. Rockfalls and landslides can occur spontaneously and without warning. Volcanic earthquakes or explosive eruptions in the caldera would likely increase the frequency of large rockfalls. The steep flow fronts of large, active lava flows and lava domes can also generate rockfalls and landslides, and these events can be followed by small pyroclastic flows and surges. The areas of greatest hazard from rockfalls and landslides are steep rock walls or near the base of those slopes.

\section{Volcanic Gases}

Prior to, during, and immediately after volcanic eruptions, large volumes of volcanic gases are commonly emitted; the most common are water, sulfur dioxide, carbon dioxide, and hydrogen sulfide. Carbon monoxide, chlorine, and fluorine gases can also be present in trace amounts. Hydrogen sulfide is often brownish in color and smells like rotten eggs, and sulfur dioxide can have a bluish tint and has an irritating, pungent odor much like a just-struck match. Both carbon dioxide and carbon monoxide are colorless and odorless. When first emitted, these gases can be very hot $\left(>600^{\circ} \mathrm{C}\right)$; temperatures quickly drop with distance from the vent and the mixing of cool air. Even during non-eruptive periods, volcanic gases can sometimes build to dangerous levels in basins and low, protected areas. Carbon dioxide is heavier than air, and can collect in low-lying, wind-blocked areas, posing a suffocation hazard to animals and humans in the area.

When these gases, particularly sulfur, chlorine, and fluorine, interact with water, they can form microscopic droplets and aerosols of sulfuric acid, hydrochloric acid, and hydrofluoric acid. Gases released into bodies of water can significantly reduce the $\mathrm{pH}$ of the water, forming acid lakes or streams. If significant quantities of these acids are mixed with rain or snow, highly acidic precipitation can result. Acidic volcanic aerosols can cause skin and lung irritation, and corrode paint, fabric, and metals.

In 2005, an acid flood traveled down the flanks of Mount Chiginagak volcano on the Alaska Peninsula. The flood acidified the waters downstream, killing all aquatic life, and the acidic aerosols that accompanied the flood killed or damaged plant life up to 150 meters above the stream banks over a 29-square-kilometer area (Schaefer and others, 2008). This type of event is rare and has not been documented at Fisher volcano.

Volcanic gases heat Turquoise lake to $\sim 13^{\circ} \mathrm{C}\left(55^{\circ} \mathrm{F}\right)$, and plumes of heated water stir lake sediments to give the lake its bluish-green color (fig. 17A). Volcanic gases also heat a series of warm pools $\sim 1$ kilometer south of Turquoise lake, the hottest of which was $44^{\circ} \mathrm{C}\left(111^{\circ} \mathrm{F}\right)$ in August 2000 . These pools feed a warm stream (fig. 17B), which flows south toward the southern outflow canyon. A series of small warm-water plumes appeared in the western caldera lake during the summer of 2000 (fig. 17C), but were gone by the following year.

Fumaroles, or jets of hot volcanic gas, on the upper reaches of Mt. Finch were intermittently active during the summers of 1999-2001 (fig. 17D). The temperatures of these fumaroles have not been measured. No other active fumaroles have been observed in the caldera. Light tan patches of alteration on the inside wall of the northern caldera rim indicate fumaroles were once present, but are not currently active.

The greatest hazards from volcanic gases and acidic aerosols during future eruptions will occur within a few hundred meters to a few kilometers of active vents, depending on wind velocity and direction.

\section{Phreatomagmatic Explosions}

The interaction of magma and water can result in a violent explosion as the water flashes to steam. These explosions, known as phreatomagmatic eruptions, generally produce low-altitude ash clouds. In some cases, the rapid expansion of water can generate violent pyroclastic surges (see above) that can send volcanic material a significant distance - up to 10 kilometers at Fisher volcano based on mapped deposits (fig. 18). Phreatomagmatic eruptions often excavate circular, steep-walled craters, known as maars (fig. 19). Maar craters commonly fill with water, forming lakes. Locations of future phreatomagmatic eruptions are difficult to anticipate, as the magma-water interaction can occur when magma injects into an existing body of water or when magma interacts with groundwater, commonly near but not at existing vents. There are several maars in Fisher's caldera and at least one outside the caldera (fig. 5). Thick (up to 100 meters) phreatomagmatic deposits found in many locations inside and outside the caldera indicate violent eruptive activity. In all, more than 450 square kilometers at Fisher volcano have been affected by phreatomagmatic eruptions.

Phreatomagmatic eruptions at Fisher are likely to occur in the future. Although the location of maar eruptions are difficult to predict, and phreatomagmatic eruptions could occur anywhere inside or on the flanks of the volcano, existing maar craters in the caldera are generally aligned along the long axis of the caldera (northeast-southwest; fig. 5). Regions along this lineament, particularly those near standing water, are especially vulnerable to future phreatomagmatic explosions. 


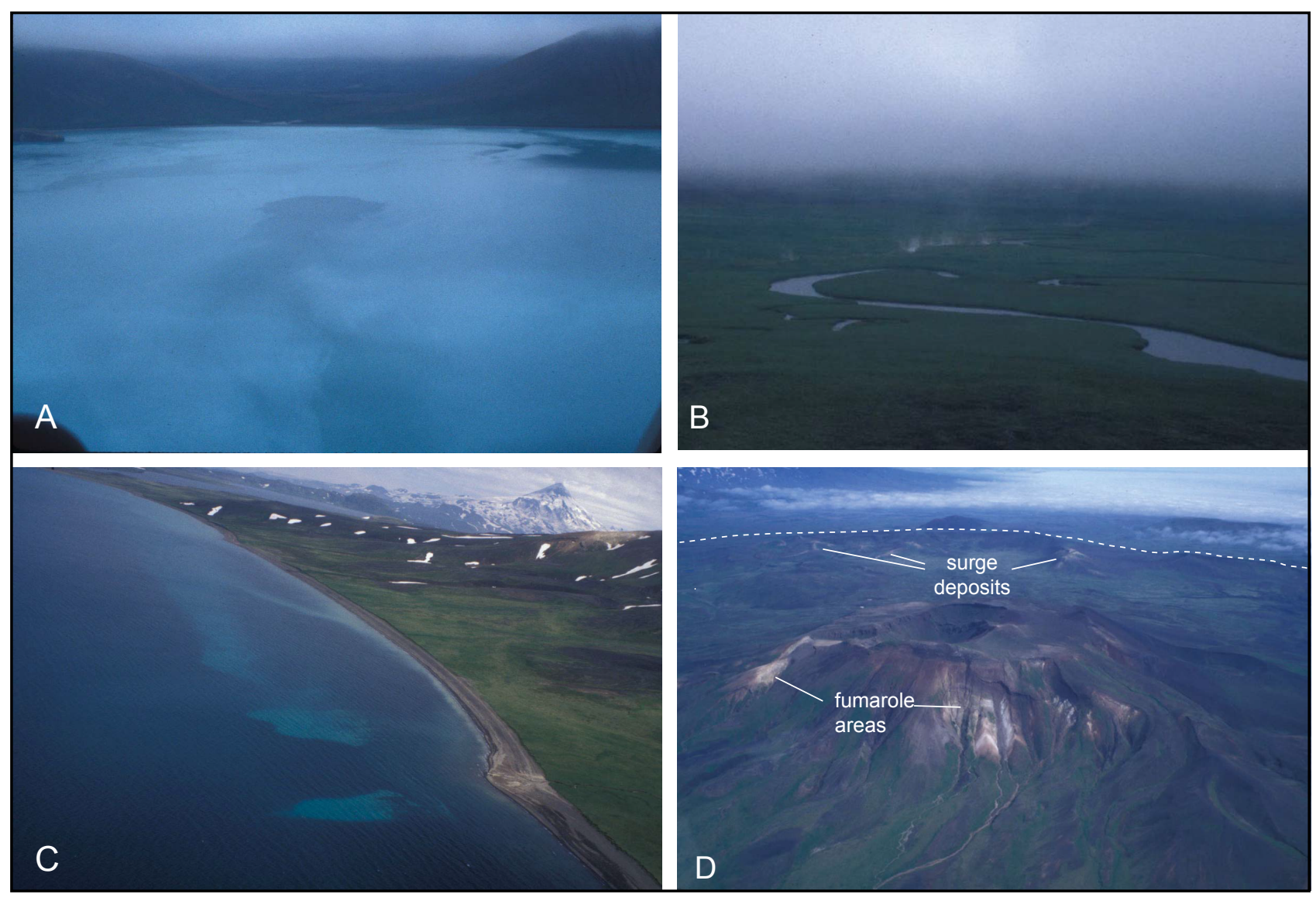

Figure 17. Areas of Fisher volcano affected by volcanic gases and thermal upwelling. A. Plumes of warm water in Turquoise lake stir sediment and give the lake its characteristic blue-green color. B. Steam plumes mark the location of warm $\left(>110^{\circ} \mathrm{F}\right)$ springs in the southern caldera floor. These springs feed a warm stream that ultimately flows out of the southern outflow canyon. C. Intermittent plumes of sediment in the west caldera lake, likely due to rising warm water. These plumes were observed in 2000 but were absent in 1999 and 2001. D. Alteration of the flanks of Mt. Finch indicates regions of fumarolic activity. Intermittent fumaroles were observed here during 1999, 2000, and 2001. Light-colored surge deposits from phreatomagmatic eruptions in the caldera are also visible on ridge crests. Dashed white line is the eastern caldera rim. All photos: P. Stelling, 2000.

\section{OTHER HAZARDS}

\section{Debris Avalanches}

Debris avalanches are giant landslides of volcanic material formed by collapse of the upper flanks of a volcano. Debris avalanches can travel at speeds of 30 to 150 kilometers per hour, and can extend up to 20 kilometers or more from their source, burying large areas beneath many meters of coarse volcanic debris. Volcanic debris avalanches can be triggered by eruptions or large earthquakes, or can occur spontaneously without other stimulus, especially in areas of intense fracturing or chemical alteration (Begét and Kienle, 1992).

At Fisher volcano, several debris-avalanche deposits are present outside the caldera margins. One deposit, observed only outside the southern caldera rim, lies at the base of and grades into the basal surge deposits of the caldera-forming eruption rock sequence, indicating a major collapse during caldera formation. Other smaller debris-avalanche deposits appear to be older than $\sim 9,400$ years. The major collapse of Turquoise cone likely produced a significant debris avalanche, although deposits from this event are not obvious in the caldera. The remnants of the original Turquoise cone could have been weakened as a result of the collapse, and the steep walls of Turquoise cone are a likely location for future debris avalanches to occur. If such an event were to occur, the debris avalanche could travel into Turquoise lake and displace significant volumes of water (see volcanic tsunami section below).

Based on the low frequency of debris avalanches at Fisher volcano, it is unlikely that a debris avalanche will occur in the near future. However, such an event could be catastrophic for anything in the path of the avalanche. The debris-avalanche hazard would increase if a future eruptive vent opened near the western caldera wall, or if this area became a focus of ground deformation, as the weathered and fractured rocks of Turquoise cone and the western caldera wall could readily 


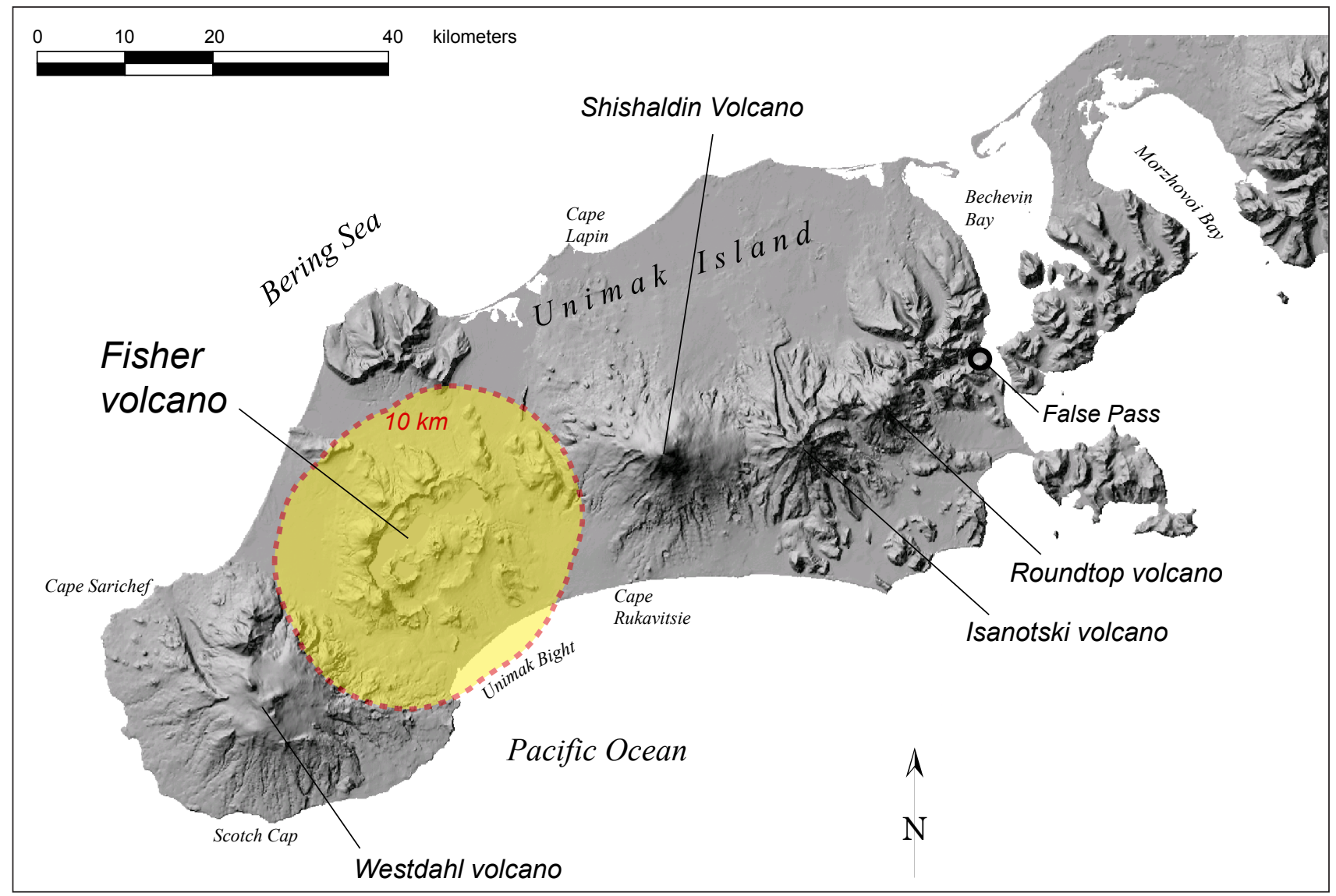

Figure 18. Maximum likely distribution of material ejected during phreatomagmatic explosions at Fisher volcano (yellow shaded area within 10 kilometers of caldera).

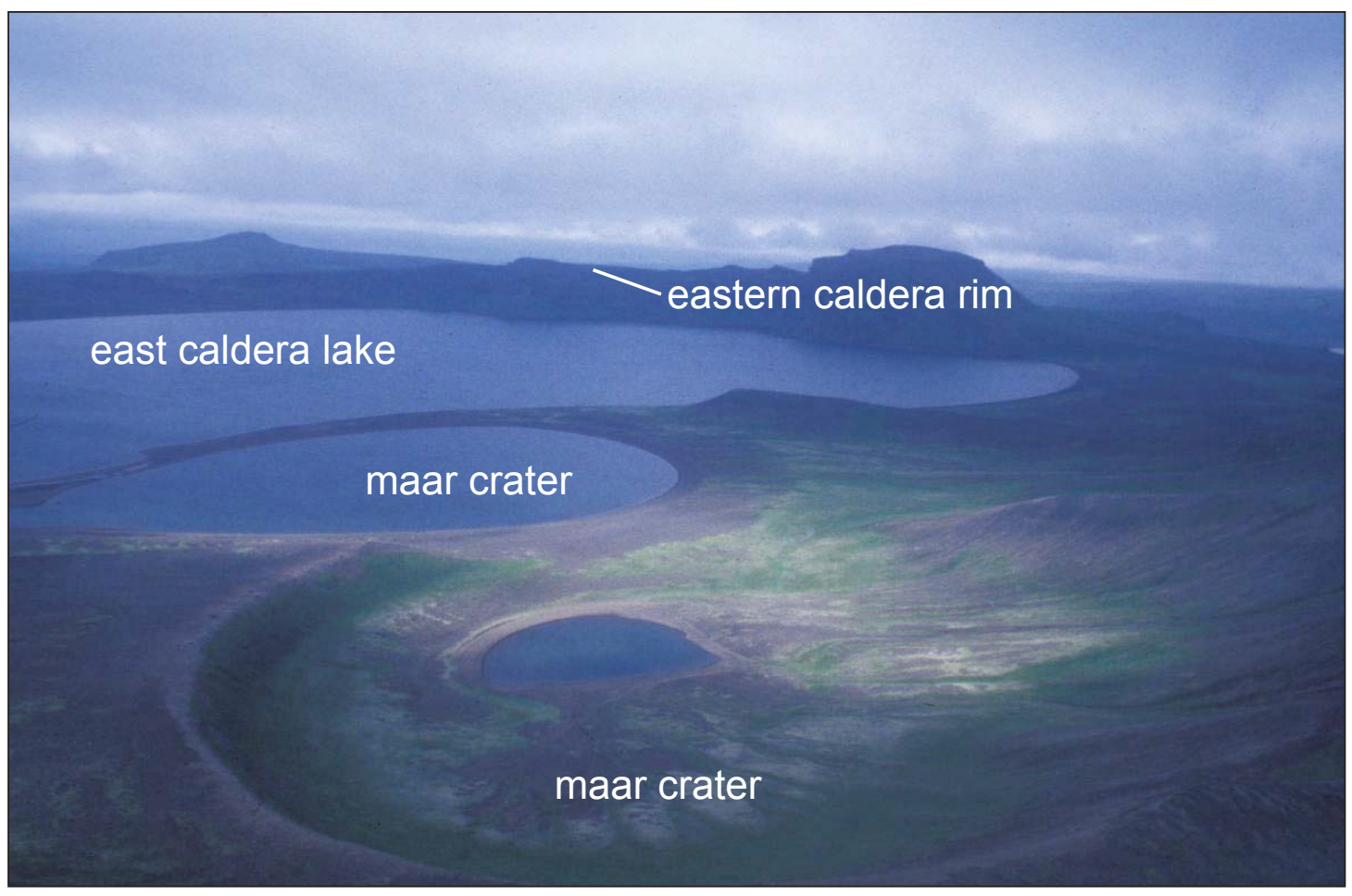

Figure 19. Maar craters on the southern shore of the east caldera lake, between Mt. Finch and the eastern caldera rim. Photo: P. Stelling, 2000. 
collapse. Based on the extent of mapped occurrences of avalanche deposits and the height of the potentially unstable rock in the area, regions within 10 kilometers of the caldera wall, both inside and outside the caldera, could be affected. Assuming any steep portion of the caldera wall could collapse and produce a debris avalanche, the entire caldera floor is exposed to this hazard.

\section{Directed Blasts}

A directed blast is an explosion that is pointed laterally away from the volcanic vent rather than vertically, as with typical volcanic eruption plumes. Lateral blasts are typically caused by flank collapse or by a debris avalanche that uncaps and depressurizes hot, gas-charged magmatic material at a volcano. Although it is impossible to preclude the possibility that a directed blast can accompany a future eruption, such events are exceedingly rare, particularly at Fisher volcano. Among the evidence for previous directed blasts at Fisher is the main phase of the caldera-forming eruption $\sim 9,400$ years ago, during which a surge of pyroclastic material traveled northward and overtopped the Tugamak Range. Such an event is anomalous at Fisher, however. Because the current topography does not indicate a location where a directed blast could occur (such as a large stratocone), these events are considered to be a minimal threat at Fisher.

\section{Volcanic Tsunamis}

Fisher Caldera is near the center of Unimak Island, flanked by the Bering Sea to the north and the Pacific Ocean to the south. Numerous tsunamis, some among the largest and most devastating known in historic time, have been generated by eruptions at volcanoes near the world's oceans (Begét, 2000). During the last 200 years about 20 percent of the known volcanic tsunamis worldwide were produced by earthquakes, whereas 80 percent were generated by volcanic explosions or following the displacement of seawater by large masses of volcanic debris entering the ocean (Latter, 1981). Voluminous pyroclastic flows and debris avalanches that flowed into the sea at high velocity have produced the largest volcanically-generated tsunamis.

No tsunamis have been produced at Fisher volcano during the relatively small eruptions of the last few hundred years, and tsunamis in the open ocean are very unlikely to be produced by typical eruptions of Fisher volcano in the future. A tsunami was likely generated during the caldera-forming eruption $\sim 9,400$ years ago when a large pyroclastic flow overran the Tugamak Range and entered the Bering Sea on the northern flanks of the volcano. Although tsunami deposits from this event have not been identified, the greater-than20-meter-thick deposits at the coast suggest a large volume of material entered the Bering Sea and displaced a similarly large volume of seawater. Large tsunamis were produced during a similar caldera-forming eruption of Aniakchak volcano on the Alaska Peninsula (Waythomas and Neal, 1998). In the unlikely event of another unusually large eruption at
Fisher, similar to the caldera-forming eruption $\sim 9,400$ years ago, tsunami waves could be generated in either the Bering Sea or the Pacific Ocean. If such an event were to occur, all coastal areas at low elevations around the northern and southern parts of Unimak Island could be affected. Additionally, tsunami waves could propagate across the ocean in some or all directions. Humans can reduce their risk by climbing to sites at higher elevation.

Small tsunamis could be generated in Fisher Caldera's lakes either as a result of explosive eruptions or by the collapse of unstable rock, sending debris flows or avalanches into the lakes. These events could violently displace significant volumes of water that could inundate local drainages and low-lying areas. There is evidence for eruptive activity beneath the caldera lakes, including two maar craters on the shores of the eastern caldera lake. Additionally, the draining of the southern portion of the caldera could have resulted from a lacustrine tsunami produced during a phreatomagmatic eruption in the caldera $1,500 \mathrm{yr}$ BP. If a future eruption of Fisher volcano occurs beneath one of the caldera lakes, water could wash over the lake shore and flood nearby low-lying areas in the caldera, and floodwaters could travel outside the caldera through the southern outflow canyon or possibly over low portions of the eastern caldera rim.

\section{COULD ANOTHER CALDERA-FORMING ERUPTION OCCUR AT FISHER?}

The formation of calderas is an exceedingly rare event, but the associated eruptions can have catastrophic results. Eruptions similar in magnitude to those that occurred at Fisher volcano $\sim 9,400$ years ago are estimated to occur globally only about once per century to once every thousand years. Eruptions of such a large magnitude can have dramatic effects at distances of tens to hundreds of kilometers away from the volcano, as well as globally. For instance, the 1883 caldera-forming eruption at Krakatau volcano in Indonesia produced about 20 cubic kilometers of tephra, sending pyroclastic flows and surges across water as far as 40 kilometers from the volcano, killing 4,000-5,000 people, and generating tsunami waves 15 to 30 meters high that inundated the shorelines of nearby islands, killing an additional 32,000 people (Tanguy and others, 1998). A larger caldera-forming eruption at nearby Mount Tambora volcano in 1815 produced about 100 cubic kilometers of tephra, killing about 11,000 people and inducing global climate cooling that affected areas as far away as North America and Europe, and led to about 49,000 fatalities in Indonesia from crop failures and disease (Tanguy and others, 1998). The explosion that formed Fisher Caldera is estimated to have erupted an amount of volcanic material comparable to the Tambora eruption of 1815 (Carey and others, 1996).

Could Fisher volcano once again be the site of such a huge eruption? Our data suggest the recurrence of such an eruption is possible, but not likely in the near future. We know from geologic studies that Fisher has undergone numerous 
relatively small eruptions since the caldera-forming event $\sim 9,400$ years ago. This pattern of activity clearly shows that shallow magma reservoirs reformed under Fisher volcano soon after the caldera-forming eruption and are likely present today. This pattern of activity also allows us to say with some confidence that more similarly sized eruptions are highly likely to occur in the future. At Okmok volcano, about 500 kilometers west of Fisher, there have been at least two caldera-forming eruptions, one about 12,000 years ago and a second about 2,000 years ago (Larsen and others, 2007). Two caldera-forming eruptions at Aniakchak volcano were separated by at most 6,500 years (Neal and others, 2001), which can serve as a younger limit for the recurrence interval of caldera-forming eruptions. Many volcanoes of the world only go through a single caldera-forming eruption; multiple caldera-forming eruptions at a single volcano are rare.

\section{ERUPTION FREQUENCY AND VOLCANIC RISK AT FISHER VOLCANO}

The historical record and our geologic studies of prehistoric deposits suggest that Fisher volcano erupts often, although less frequently than neighboring Shishaldin or Westdahl volcanoes. Of the three historic eruptions attributed to Fisher during the last 250 years (Simkin and Siebert, 1994), several might have been incorrectly attributed to Fisher and could actually have been eruptions of Shishaldin or Westdahl volcanoes. Ash deposits on the caldera floor suggest there has been only one recent (historic) eruption, the date of which is uncertain. The prehistoric pattern of eruptions, interpreted from the recognition of numerous tephra deposits preserved in the caldera, implies a recurrence interval of approximately 250 years between such events. Recurrence interval calculations probably underestimate the actual frequency of eruptions at Fisher, because some prehistoric eruptions likely did not leave recognizable deposits or those deposits were quickly eroded, and some eruptions during historic time likely went unobserved.

The record of activity at Fisher volcano suggests that eruptions could occur during the 21 st century. The primary volcanic hazard during future eruptions will be from volcanic ash clouds depositing ash locally on eastern Unimak Island, and then drifting over other Aleutian Islands, parts of the North Pacific Ocean, and over mainland Alaska and North America. Ash clouds can interfere with operations of the international airports at Dutch Harbor and Cold Bay, as well as the dozens of commercial and passenger jet flights that fly between Asia, Europe, and North America across the North Pacific each day. During large eruptions, aircraft operations around Fisher volcano and areas of the North Pacific through which volcanic ash is dispersed could be affected for extended periods of time, and ash fallout on False Pass, the nearest populated city, could be a few millimeters to a few centimeters thick if prevailing winds carried ash clouds eastward. Ashfall could interfere with the operation of engines and generators, and would affect commercial and civic activities. On Unimak Island, the caldera and some areas on the flanks of Fisher are likely to be affected by floods, lahars, and small surges and pyroclastic flows during future eruptions. The exact areas outside the caldera that might be affected are impossible to predict, but the region inside the caldera and areas outside the caldera to the east and south along the southern outflow canyon are at greater risk.

Evaluating the frequency and risk from significantly larger eruptions is much more difficult. An eruption as large as the caldera-forming event $\sim 9,400$ years ago could have very serious consequences, but the likelihood of such an eruption in the near future is practically nil. In addition to airborne ash, the greatest hazard from such a large, rare eruption would be the generation of highly mobile pyroclastic flows and surges with the potential to travel 40 kilometers or more from the volcano. These flows would be devastating to the plant and animal life on central Unimak Island, and would probably travel some distance across the sea, possibly generating tsunamis. A large, explosive eruption would also produce much more widespread and longer-lived ash clouds over the North Pacific Ocean air traffic corridors, and near Cold Bay could produce ashfall as thick as 5 to 10 centimeters or more.

\section{PRECURSORY ACTIVITY, VOLCANO MONITORING, AND HAZARD MITIGATION}

The Alaska Volcano Observatory (AVO), a joint facility of the U.S. Geological Survey, the Geophysical Institute of the University of Alaska Fairbanks, and the Division of Geological \& Geophysical Surveys of the State of Alaska's Department of Natural Resources, was established in 1988 to evaluate volcano hazards in Alaska, and issue warnings of imminent volcanic eruptions (Eichelberger and others, 1995). Scientists from AVO have established a network of instruments on Unimak Island to monitor earthquakes and ground deformation that will almost certainly precede any future volcanic eruptions. In most cases volcanic eruptions are preceded by hours to months of earthquakes, providing warning of future eruptions. Any significant eruption at Fisher volcano would likely be preceded by migration of magma and other fluids toward the ground surface in the caldera, producing many small to moderately large earthquakes. Some of the larger earthquakes might be felt by people living in the False Pass area.

Although no seismic instruments are installed on Fisher volcano, AVO has been monitoring volcanic activity on Unimak Island since 1998 with real-time seismic networks on Isanotski, Shishaldin and Westdahl volcanoes (fig. 20) that can automatically signal increases in frequency and magnitude of seismic activity (earthquakes). Radio-telemetry connects the seismometers and transmits the data to receiver sites in Cold Bay and Akutan, where the signal is uploaded to telephone lines and sent on to AVO laboratories in Fairbanks and Anchorage. Fisher volcano lies outside all of the seismic networks on Unimak Island, and thus only earthquakes 
larger than about magnitude 2.0 can be detected there. In the event of volcanic unrest, it is likely that AVO would deploy a temporary seismic network around Fisher volcano to detect smaller earthquakes. The AVO staff is experienced in recognizing precursory seismic activity, and will likely be able to provide warning of future eruptions of Fisher volcano.

AVO uses additional monitoring techniques to better predict the timing and magnitude of a potential eruption. Daily satellite observations of the volcano are used to detect any thermal anomaly and to identify and track any ash erupted into the atmosphere. In the event of precursory activity, intermittent airborne or ground-based measurements can be made to track changes in volcanic gas emissions, millimeter-scale ground motion, or temperatures of fumaroles and lava cones. Recently, web cameras have been deployed to monitor remote volcanic activity by transmitting near-realtime images to AVO.

AVO uses both an Aviation Color Code system and on-the-ground Volcano Alert Level to summarize the volcano-hazard status of volcanoes in Alaska (fig. 21) (Gardner and Guffanti, 2006). Use of the Aviation Color Code and Volcano Alert Levels allow AVO to quickly communicate changes in volcanic activity to government agencies, which can then make informed decisions about response to eruptions. AVO reports the status of 27 monitored volcanoes in Alaska, including Fisher volcano, through the fax, e-mail, and internet distribution of Volcanic Activity Notifications (VANs), which can take several forms. A Weekly Update is issued every Friday and contains the current weekly summary of all monitored volcanoes. Information Releases are periodic reports to provide information about a significant change at a particular volcano. If a volcano is at an elevated alert level or elevated aviation color code, a daily Status Report is issued to report any new information or significant observations. These frequent VANs keep other government agencies and the public informed about significant changes in volcanic activity. In addition to the VANs, during times of volcanic crisis AVO staff follow a formal call-down protocol, making calls directly to the Federal Aviation Administration, the National Weather Service, local U.S. military bases and airports, the Governor's Office of the State of Alaska, the Alaska Department of Emergency Services, airports and air carriers, and municipal and other civil authorities in the areas around the volcano. To make this information available as widely as possible in a timely fashion, VANs are posted on the AVO website (http://www.avo.alaska.edu/).

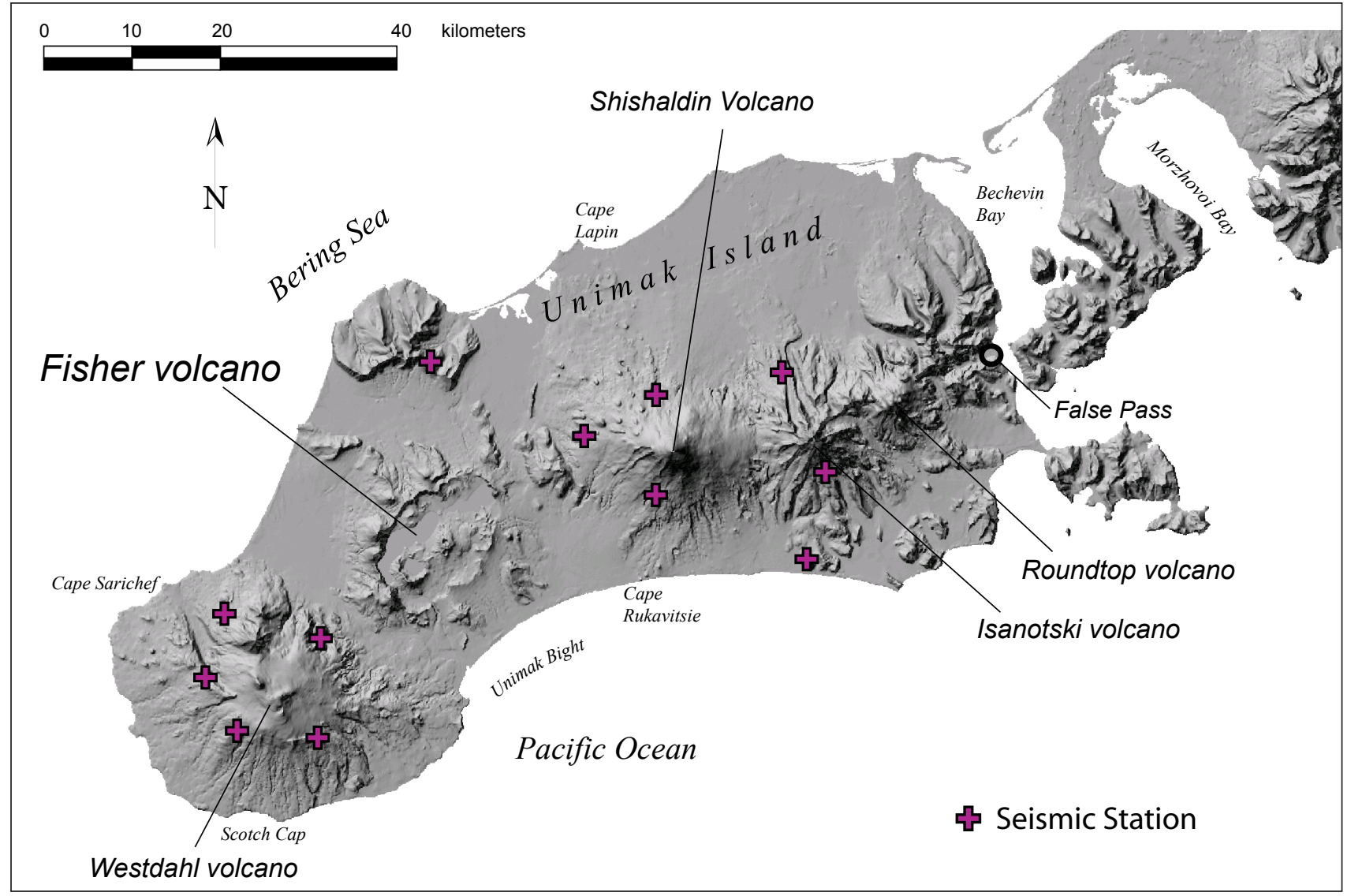

Figure 20. Locations of seismic monitoring stations on Unimak Island. These networks are capable of detecting small earthquakes beneath Isanotski, Shishaldin, and Westdahl volcanoes that could signal the onset of a volcanic eruption. These networks are near enough to Fisher volcano to detect larger (> magnitude 2.0) seismic events. 
The flanks of Fisher volcano are currently uninhabited, but recreational users including hunters visit Fisher and surrounding areas on Unimak Island. Potential visitors to Fisher volcano are advised to check the latest VANs before making an extended stay near the volcano.

If signs of volcanic unrest and magma migration were detected at Fisher, AVO would begin intensive monitoring. In some cases, AVO would institute 24-hour-a-day staffing to ensure continuous seismic event monitoring. AVO would frequently communicate information about the status of the volcano as well as interpretations of the volcanic activity to local, state, and federal officials and the media through previously established communication channels. If AVO determined that an eruption was imminent, a warning would be released immediately by fax, telephone calls, email, and a posting on the AVO website, together with a discussion of likely impacts of the eruption.
When an eruption begins, an announcement is be made to all critical government, military, and civil defense officials. Depending on the size and impact of the volcanic activity, AVO would combine satellite observations, seismic monitoring, geodetic changes, observational overflights, on-site observation, and reports by pilots and other observers to interpret the behavior of the volcano and rapidly detect and report any changes in the course of the eruption. AVO would cooperate with the National Weather Service and local officials in giving warnings to areas that might be affected by ashfall.

AVO would also release a Volcanic Activity Notification when the eruption decreases in intensity or stops, and would continue to monitor the volcano for any sign of a resumption of eruption activity. Finally, AVO would undertake scientific studies of the volcanic deposits and the instrumental record of the eruption and its precursors to better understand the behav-

\begin{tabular}{|c|c|}
\hline $\begin{array}{l}\text { Volcano } \\
\text { Alert Levels are intend } \\
\text { decreasing volcanic ac }\end{array}$ & $\begin{array}{l}\text { t Levels Used by USGS Volcano Observatories } \\
\text { form people on the ground about a volcano's status and are issued in conjunction with the Aviation Color Code. Notifications are issued } \\
\text { Id are accompanied by text with details (as known) about the nature of the unrest or eruption and about potential or current hazards and }\end{array}$ \\
\hline Term & Description \\
\hline NORMAL & $\begin{array}{l}\text { Volcano is in typical background, noneruptive state } \\
\text { or, after a change from a higher level, } \\
\text { volcanic activity has ceased and volcano has returned to noneruptive background state. }\end{array}$ \\
\hline ADVISORY & $\begin{array}{l}\text { Volcano is exhibiting signs of elevated unrest above known background level } \\
\text { or, after a change from a higher level, } \\
\text { volcanic activity has decreased significantly but continues to be closely monitored for possible renewed increase. }\end{array}$ \\
\hline WATCH & $\begin{array}{l}\text { Volcano is exhibiting heightened or escalating unrest with increased potential of eruption, timeframe uncertain, } \\
\text { OR } \\
\text { eruption is underway but poses limited hazards. }\end{array}$ \\
\hline WARNING & Hazardous eruption is imminent, underway, or suspected. \\
\hline
\end{tabular}

\begin{tabular}{|c|c|}
\hline \multicolumn{2}{|c|}{$\begin{array}{l}\text { Aviation Color Code Used by USGS Volcano Observatories } \\
\text { color codes, which are in accordance with recommended International Civilian Aviation Organization (ICAO) procedures, are intended to inform the aviation sector about a volcano's status and are } \\
\text { issued in conjunction with an Alert Level. Notifications are issued for both increasing and decreasing volcanic activity and are accompanied by text with details (as known) about the nature of the } \\
\text { unrest or eruption, especially in regard to ash-plume information and likely outcomes. }\end{array}$} \\
\hline Color & Description \\
\hline GREEN & $\begin{array}{l}\text { Volcano is in typical background, noneruptive state } \\
\text { or, after a change from a higher level, } \\
\text { volcanic activity has ceased and volcano has returned to noneruptive background state. }\end{array}$ \\
\hline YELLOW & $\begin{array}{l}\text { Volcano is exhibiting signs of elevated unrest above known background level } \\
\text { or, after a change from a higher level, } \\
\text { volcanic activity has decreased significantly but continues to be closely monitored for possible renewed increase. }\end{array}$ \\
\hline ORANGE & $\begin{array}{l}\text { Volcano is exhibiting heightened or escalating unrest with increased potential of eruption, timeframe uncertain, } \\
\text { OR } \\
\text { eruption is underway with no or minor volcanic-ash emissions [ash-plume height specified, if possible] }\end{array}$ \\
\hline RED & $\begin{array}{l}\text { Eruption is imminent with significant emission of volcanic ash into the atmosphere likely } \\
\text { OR } \\
\text { eruption is underway or suspected with significant emission of volcanic ash into the atmosphere [ash-plume height specified, if possible] }\end{array}$ \\
\hline
\end{tabular}

Figure 21. Top. The USGS Alert Notification System for Volcanic Activity (from Gardner and Guffanti, 2006). Bottom. Volcano Alert Levels and Aviation Color Code used by the Alaska Volcano Observatory (AVO). Alert Levels and Aviation Color Codes are updated based on changing conditions, and are used to quickly indicate the status of Fisher Caldera and other Alaska volcanoes. The current Alert Level and Color Code including written explanations and updates are distributed to government agencies, the media, airlines, and the public, and are posted on the AVO website. 
ior of Fisher volcano and to improve the overall knowledge of volcanic hazards and volcano monitoring.

\section{WHAT CAN BE DONE TO PREPARE FOR AN ERUPTION AT FISHER VOLCANO?}

Fisher volcano will erupt again. Individual citizens and concerned government officials can help mitigate the impacts of future eruptions by being aware of the potential hazards and by taking steps to prepare for them. The keys to preparing for a volcanic eruption are being aware of the hazards, educating the community, and developing and practicing an effective emergency plan. Although Fisher does not erupt frequently, potential hazards are still present, and preventative measures for volcanic eruption are similar to those for other natural disasters faced by Alaskans, such as flooding, earthquakes, and extreme weather. Local communities should have emergency supplies of food, water, and fuel, and have a plan to deal with disruption of normal services and communication. Because of the possibility of ash infiltrating mechanical systems, maintaining a supply of replacement air filters for all internal combustion engines is advisable. Although the area in the immediate vicinity of Fisher volcano is very lightly populated and is not currently experiencing population growth or development, volcanic hazards should be factored into future plans for land use and development of areas that might be affected by volcanic phenomena during future eruptions. Public officials and land managers should develop, practice, and continually update emergency-response plans for areas and populations that might be affected by volcanic phenomena during future eruptions.

As of 2010, about 1,700 people live within 125 kilometers of Fisher volcano. This number can increase significantly during the fishing season when many fishing boats and workers travel to Akutan, King Cove, Cold Bay, and False Pass to fish along the Aleutian Islands and in the Bering Sea. At Fisher itself, small groups of hunters are usually present seasonally in or around the area. Property owners, Native tribal authorities, and government officials and land managers should be aware of the potential hazards that could accompany future eruptions of Fisher volcano, and develop emergency response plans. Residents of False Pass and other nearby communities, visitors to the area, and fishermen who sail close to Unimak Island should also be aware of the hazards that could accompany future eruptions of Fisher volcano.

\section{REFERENCES}

Baxter, P.J., Neri, A., and Todesco, M., 1998, Physical modelling and human survival in pyroclastic flows: Natural Hazards, v. 17, no. 2, p. 163-176. doi:10.1023/A:1008031004183

Begét, J.E., ed., 2000, Volcanic tsunamis [in Part VII, Volcanic Hazards], in Sigurdsson, Haraldur, Houghton, Bruce, McNutt, S.R., Rymer, Hazel, and Stix, John, eds., Encyclopedia of Volcanoes: San Diego, Academic Press, p. $1,005-1,014$.
Begét, J.E., and Kienle, Juergen, 1992, Cyclic formation of debris avalanches at Mount St. Augustine Volcano: Nature, v. 356, no. 6,371, p. 701-704.

Begét, J.E., Nye, C.J., Schaefer, J.R., and Stelling, P.L., 2003, Preliminary volcano-hazard assessment for Shishaldin Volcano, Alaska: Alaska Division of Geological \& Geophysical Surveys Report of Investigation 2002-4, 28 p., 1 sheet, scale 1:500,000. doi:10.14509/2872

Bindeman, I.N., Fournelle, J.H., and Valley, J.W., 2002, 9,100 BP eruption of Fisher Caldera, Unimak, AleutiansLow-delta ${ }^{18} \mathrm{O}$ zoned tuff, a tephrochronological marker: Journal of Volcanology and Geothermal Research, v. 111, no. $1-4$, p. $35-53$.

Blong, R.J., 1984, Volcanic Hazards-A sourcebook on the effects of eruptions: Sydney, Australia, Academic Press, $424 \mathrm{p}$.

Blong, R.J., 1996, Volcanic hazards risk assessment, in Scarpa, R., and Tilling, R.I., eds., Monitoring and mitigation of volcano hazards: Berlin, Springer-Verlag, p. 675-698.

Brantley, S.R., 1990, The eruption of Redoubt Volcano, Alaska, December 14, 1989-August 31, 1990: U.S. Geological Survey Circular 1061, 33 p.

Carey, S.N., Sigurdsson, Haraldur, Mandeville, C.W., and Bronto, S., 1996, Pyroclastic flows and surges over water-an example from the 1883 Krakatau eruption: Bulletin of Volcanology, v. 57, no. 7, p. 493-511.

Carson, E.C., 1998, Holocene tephrochronology of the Cold Bay area, southwest Alaska Peninsula: Madison, Wisconsin, University of Wisconsin, M.S. Thesis, 178 p.

Carson, E.C., Fournelle, J.H., Miller, T.P., and Mickelson, D.M., 2003, Holocene tephrochronology of the Cold Bay area, southwest Alaska Peninsula: Quaternary Science Reviews, v. 21, no. 21-22, p. 2,213-2,228.

Casadevall, T.J., 1994, Volcanic ash and aviation safetyProceedings of the first international symposium on volcanic ash and aviation safety: U.S. Geological Survey Bulletin 2047, 450 p.

Coats, R. R., 1950, Volcanic activity in the Aleutian Arc: U.S. Geological Survey Bulletin B 0974-B, p. 35-49, 1 sheet, scale unknown.

Cole, P.D., Calder, E.S., Sparks, R.S.J., Clarke, A.B., Druitt, T.H., Young, S.R., Herd, R.A., Halford, C.L., and Norton, G.E., 2002, Deposits from dome-collapse and fountain-collapse pyroclastic flows at Soufriere Hills Volcano, Montserrat, in Druitt, T.H., and Kokelaar, B.P., eds., The Eruption of Soufriere Hills Volcano, Montserrat, from 1995 to 1999: Geological Society, London, Memoirs, v. 21, p. 231-262.

Eichelberger, J.C., Keith, T.E.C., Miller, T.P., and Nye, C.J., 1995, The 1992 eruptions of Crater Peak vent, Mt. Spurr Volcano, Alaska: U.S. Geological Survey Bulletin 2139, p. $1-18$.

Fournelle, J.H., 1990, Geology and geochemistry of Fisher Caldera, Unimak Island, Aleutians - Initial results: Transactions of the American Geophysical Union, v. 71, p. 1,698-1,699. 
Funk, J.M., 1973, Late Quaternary geology of Cold Bay, Alaska, and vicinity: Groton, University of Connecticut, M.S. Thesis, $45 \mathrm{p}$.

Gardner, C.A., and Guffanti, M.C., 2006, U.S. Geological Survey's alert notification system for volcanic activity: U.S. Geological Survey Fact Sheet 2006-3139, 4 p.

Gardner, J.E., Burgisser, Alain, and Stelling, P.L., 2007, Eruption and deposition of the Fisher Tuff (Alaska) Evidence for the evolution of pyroclastic flows: Journal of Geology, v. 115, p. 417-435.

Grewingk, Constantine, 1850, Geology of Alaska and the northwest coast of America-Contributions toward knowledge of the orographic [topographic] and geognostic [geologic] condition of the northwest coast of America, with the adjacent islands - Translated by Fritz Jaensch from Verhandlungen der Russich-Kaiserlichen Mineralogischen Gesellschaft zur St. Petersburg, Jahren 1848 und 1849: Fairbanks, University of Alaska Press, Rasmuson Library Historical Translations Series, 2003, v. 11,242 p..

Johnston, D.M., 1997, Physical and social impacts of past and future volcanic eruptions in New Zealand: Palmerston North, New Zealand, Massey University, unpublished Ph.D. dissertation.

Kieffer, S.W., 1981, Blast dynamics at Mount St. Helens on 18 May 1980: Nature, v. 291, no. 5816, p. 568-570.

Larsen, J.F., Neal, C.A., Schaefer, J.R., Begét, J.E., and Nye, C.J., 2007, Late Pleistocene and Holocene caldera-forming eruptions of Okmok Caldera, Aleutian Islands, Alaska, AGU Geophysical Monograph, Volcanism and Subduction: The Kamchatka Region, p. 343-364.

Latter, J.H., 1981, Tsunamis of volcanic origin: Bulletin of Volcanology, v. 44, no. 3, p. 467-490.

Miller, T.P., McGimsey, R.G., Richter, D.H., Riehle, J.R., Nye, C.J., Yount, M.E., and Dumoulin, J.A., 1998, Catalog of the historically active volcanoes of Alaska: U.S. Geological Survey Open File Report 98-582, 104 p.

Miller, T.P., and Smith, R.L., 1977, Spectacular mobility of ash flows around Aniakchak and Fisher calderas, Alaska: Geology, v. 5, no. 3, p. 173-176.

Myers, B.M., Brantley, S.R., Stauffer, P.H., and Hendley, J.W., II, 1997, What are volcano hazards?: U.S. Geological Survey Fact Sheet 002-97, 2 p.

Neal, C.A., McGimsey, R.G., Miller, T.P., Riehle, J.R., and Waythomas, C.F., 2001, Preliminary volcano-hazard assessment for Aniakchak volcano, Alaska. U.S. Geological Survey Open File Report 00-519, 35 p., 1 plate.
Schaefer, J.R., Cameron, C.E., and Nye, C.J., 2014, Historically active volcanoes of Alaska, in Schaefer, J.R., Cameron, C.E., and Nye, C.J., Historically active volcanoes of Alaska: Alaska Division of Geological \& Geophysical Surveys Miscellaneous Publication 133 v. 1.2, 1 sheet, scale 1:3,000,000. doi:10.14509/20181

Schaefer, J.R., Scott, W.E., Evans, W.C., Jorgenson, Janet, McGimsey, R.G., and Wang, Bronwen, 2008, The 2005 catastrophic acid crater lake drainage, lahar, and acidic aerosol formation at Mount Chiginagak volcano, Alaska, USA-Field observations and preliminary water and vegetation chemistry results: Geochemistry, Geophysics, Geosystems, v. 9, no. 7, 29 p., Q07018, doi:10.1029/2007GC001900

Scott, W.E., 1989, Volcanic and related hazards, in Tilling, R.E., ed., Volcanic Hazards: Washington, D.C., American Geophysical Institute, p. 9-23.

Simkin, Tom, and Siebert, Lee, 1994, Volcanoes of the world - A regional directory, gazetteer, and chronology of volcanism during the last 10,000 years: Tucson, Geoscience Press, $349 \mathrm{p}$.

Stelling, P.L., Gardner, J.E., and Begét, J.E., 2005, Eruptive history of Fisher Caldera, Alaska, USA: Journal of Volcanology and Geothermal Research, v. 139, no. 3-4, p. $163-183$.

Swanson, S.E., and Begét, J.E., 1994, Melting properties of volcanic ash, in Casadevall, T.J., ed., Volcanic ash and aviation safety-Proceedings of the First International Symposium on Volcanic Ash and Aviation Safety: U.S. Geological Survey Bulletin 2047, p. 87-92.

Tanguy, J.C., Ribiere, C., Scarth, Alwyn, and Tjetjep, W.S., 1998, Victims from volcanic eruptions-A revised database: Bulletin of Volcanology, v. 60, no. 2, p.137-144.

Waythomas, C.F., Dorava, J.M., Miller, T.P., Neal, C.A., and McGimsey, R.G., 1998, Preliminary volcano-hazard assessment for Redoubt Volcano, Alaska: U.S. Geological Survey Open File Report 97-857, 40 p.

Waythomas, C.F., and Neal, C.A., 1998, Tsunami generation during the 3,500 year B.P. caldera-forming eruption of Aniakchak volcano, Alaska: Bulletin of Volcanology, v. 60 , no. 2, p. 110-124.

Waythomas, C.F., and Waitt, R.B., Jr., 1998, Preliminary volcano-hazard assessment for Augustine Volcano, Alaska: U.S. Geological Survey Open File Report 98-106, 39 p. 


\section{GLOSSARY OF SELECTED TERMS}

Andesite. A fine-grained volcanic rock made up of feldspars and ferromagnesian minerals; typically has a $\mathrm{SiO}_{2}$ content of 54 to about 62 percent.

Ash. Fine fragments (less than 2 millimeters across) of lava or rock formed in an explosive volcanic eruption.

Bomb. Fragment of molten or semi-molten rock, greater than 64 millimeters in diameter, which is blown out of a volcano during an eruption. Because of their "plastic" condition, bombs are often modified in shape during their flight or on impact.

Cinder cone. A conical hill formed by the accumulation of cinders and other pyroclastic debris around a volcanic vent.

Cinders. Glassy, vesicular, volcanic fragments, ranging in size from 4 to 32 millimeters, which fall to the ground in a solid condition.

Debris avalanche. Rapidly moving, dry flows of disaggregated rock debris, sand, and silt. Volcanic debris avalanches often form by some type of structural collapse of the volcano, usually the steep front of a cooled lava dome or other parts of the upper edifice. A large part of the volcano may become unstable, break away from the volcanic massif, and become an avalanche. Debris avalanches, which may be triggered by an eruption or earthquake, move at velocities ranging from a few tens of meters per second to more than 100 meters per second and behave like complex granular flows or slide flows. They may be quite voluminous (greater than 10 cubic kilometers) and run out considerable distances (up to 85 kilometers) from their source. The resulting debris avalanche deposit usually exhibits hummocky surface morphology.

Directed blast. Large-scale volcanic explosions caused by a major landslide or slope failure, which result in a rapid drop in the pressure of the intruding magma near the surface of the volcanic edifice. The 1980 eruption of Mount St. Helens was triggered by a massive slope failure, and the subsequent laterally-directed blast affected a 180-degree sector north of the volcano and extended for several tens of kilometers outward (Kieffer, 1981). A directed blast typically travels away from the volcano at a low angle and may not be deflected by ridges or other topographic barriers. Rock debris propelled by a directed blast moves much faster than typical landslides and rockfalls. For example, at Mt. St. Helens, the initial velocity of the directed blast cloud was about 600 kilometers per hour, decreasing to about 100 kilometers per hour at a distance 25 kilometers from the volcano (Kieffer, 1981).

Edifice. The upper part of the volcanic cone, including the vent and summit areas.

Effusive eruption. An eruption dominated by the outpouring of lava onto the ground is often referred to as an effusive eruption (as opposed to the violent fragmentation of magma by explosive eruptions).
Eruption cloud. Cloud of gas, ash, and other fragments that forms during an explosive volcanic eruption and travels long distances with prevailing winds.

Eruption column. The vertical part of the eruption cloud that rises above a volcanic vent.

Fallout. A general term for debris that falls to the earth from an eruption cloud.

Fumarole. Small, vent-like crack or opening with escaping gas and steam.

Holocene epoch. The period of earth history from 10,000 years before present to the present.

Lacustrine. Of or relating to lakes.

Lahar. An Indonesian term for a debris flow containing angular clasts of volcanic material. For the purposes of this report, a lahar is any type of sediment-water mixture originating on or from the volcano. Most lahars move rapidly down the slopes of a volcano as channelized flows, delivering large amounts of sediment to the rivers and streams that drain the volcano. The flow velocity of some lahars may be as high as 20 to 40 meters per second (Blong, 1984), and sediment concentrations of greater than 75 percent are not uncommon. Large-volume lahars can travel great distances if they have an appreciable clay content ( $>3$ to 5 percent), remain confined to a stream channel, and do not significantly gain sediment while losing water. Thus, they may affect areas as far as hundreds of kilometers downstream from a volcano.

Lapilli. Ejected rock or pumice fragments between 2 and 64 millimeters in diameter.

Lateral blast. See 'directed blast'.

Lava. Molten rock that reaches the earth's surface.

Lava dome. A steep-sided mass of viscous and often blocky lava extruded from a vent; typically has a rounded top and roughly circular outline.

Maar. A low-relief, broad volcanic crater formed by a shallow, phreatomagmatic, explosive eruption. Maars typically contain a lake.

Magma. Molten rock beneath the earth's surface.

Monogenetic. A monogenetic vent is one in which only one eruption has occurred, as opposed to polygenetic vents where eruptions have occurred repeatedly over time.

Petrology. The geologic study of the origin, occurrence, structure, and history of rocks.

Phreatomagmatic eruption. An explosive volcanic eruption that results from the interaction of surface or subsurface water with magma.

Pleistocene epoch. The period of Earth's history between 1.8 million and 10,000 years before present.

Polygenetic. A polygenetic vent is one in which repeated eruptions occur over time, as opposed to a monogenetic vent, which erupts only once.

Pumice. Highly vesicular volcanic ejecta; because of its extremely low density, pumice often floats on water.

Pyroclastic. General term applied to volcanic products or processes that involve explosive ejection and fragmentation of erupting material. 
Pyroclastic flow. A dense, hot, chaotic avalanche of rock fragments, gas, and ash that travels rapidly away from an explosive eruption column, often down the flanks of the volcano (synonymous with 'ash flow'). Pyroclastic flows move at speeds ranging from 10 to several hundred meters per second and are typically at temperatures between $300^{\circ} \mathrm{C}$ and $800^{\circ} \mathrm{C}$ (Blong, 1984). Pyroclastic flows form either by collapse of the eruption column or by failure of the front of a cooling lava dome. Once these flows are initiated, they may travel distances of several kilometers and easily override topographic obstacles in the flow path. A person could not outrun an advancing pyroclastic flow.

Pyroclastic surge. A low-density, turbulent flow of finegrained volcanic rock debris and hot gas. Pyroclastic surges differ from pyroclastic flows in that they are less dense and tend to travel as a low, ground-hugging - but highly mobile - cloud that can surmount topographic barriers, or travel beyond a pyroclastic flow front.

Scoria. Coarsely vesicular pyroclastic rock that is heavier and darker than pumice.

Stratovolcano (also called a 'stratocone' or 'composite cone'). A steep-sided volcano, usually conical in shape, built of lava flows and fragmental deposits from explosive eruptions.

Strombolian. An eruption style characterized by pulse-like explosive bursts and low-level emission of ash and pyroclastic debris. Usually each burst lasts for only a few seconds, and sustained eruption columns generally do not develop.

Sulfurous. Sulfur-bearing or rich in sulfur compounds.
Surge. See 'pyroclastic surge'.

Tephra. Any type of rock fragment that is forcibly ejected from the volcano during an eruption. Tephra may be finegrained dust or 'ash' (0.0625- to 2-millimeter-diameter, silt- to sand-sized), coarser 'lapilli' (2- to 64-millimeter-diameter, sand- to pebble-sized), or large blocks or bombs ( $>64$ millimeter, cobble- to boulder-sized). When tephra is airborne, the coarsest fraction will be deposited close to the volcano, but the fine fraction may be transported long distances and can remain suspended in the atmosphere for many months. Tephra particles are typically sharp, angular, and abrasive, and are composed of volcanic glass, mineral, and rock fragments.

Tsunami. Tsunami is a Japanese word meaning 'harbor wave'. A tsunami is a wave or series of waves that are generated in a body of water by a sudden disturbance that displaces water. They are typically caused by earthquakes and landslides in coastal regions. Volcanic eruptions that displace water by depositing large amounts of volcanic debris can generate a tsunami.

Tuff cone. A volcanic crater formed by a shallow explosive eruption in an area where surface water is located above the vent. Tuff cones have bedding angles of $20-25^{\circ}$ near the rim crests.

Vent. An opening in the earth's surface through which magma erupts or volcanic gases are emitted.

Vesicular. Characterized by or containing vesicles. Vesicles are small cavities in a glassy igneous rock, formed by the expansion of a bubble of gas or steam as a rock cools and hardens. 
